\title{
Effect of the protein:carbohydrate ratio in hypoenergetic diets on metabolic syndrome risk factors in exercising overweight and obese women
}

\author{
Dawn D. Campbell and Kelly A. Meckling* \\ Department of Human Health and Nutritional Sciences, University of Guelph, Guelph, ON, Canada N1G 2W1
}

(Submitted 8 June 2011 - Final revision received 26 October 2011 - Accepted 29 November 2011 - First published online 16 January 2012)

\begin{abstract}
Overweight and obesity are growing problems both in Canada and around the world. Obesity is associated with a number of chronic diseases including type 2 diabetes and CVD, which puts a tremendous burden on the health care systems in place. The present study sought to investigate whether there were differences in the effectiveness of three low-fat, hypo- and isoenergetic diets differing in protein:carbohydrate ratio, low protein (LP, $1 \mathrm{~g}$ protein: $4 \mathrm{~g}$ carbohydrate), normal protein (NP, $1 \mathrm{~g}$ protein: $2 \mathrm{~g}$ carbohydrate) or high protein (HP, $1 \mathrm{~g}$ protein: $1 \mathrm{~g}$ carbohydrate), on weight loss and markers of the metabolic syndrome (MetS) in overweight women. Subjects were randomly assigned to receive one of three intervention diets, all of which included a 60 min exercise programme three times/week for 12 weeks. Of the total subjects, fifty-four overweight and obese local women with MetS risk factors completed the study. All groups had similar improvements in body weight, insulin sensitivity, lipid profile, blood pressure and fitness. Subjects reported that the NP diet was easier to comply with and achieved better improvements in body fat, waist circumference and waist:hip ratio, and preservation of lean mass compared with the other two diets. In conclusion, energy restriction and exercise both facilitate weight loss in overweight and obese subjects and reduce symptoms of the MetS. A diet with a 1:2 protein:carbohydrate ratio promoted better improvements than either the LP or HP diets, and may be superior in reducing long-term chronic disease risk in this population.
\end{abstract}

Key words: Weight loss: Waist circumference: High-protein diets: Insulin sensitivity

Overweight and obesity are growing problems in both industrialised countries and the developing world. According to the 2004 Canadian Community Health Survey, $23 \%$ of adult Canadians were obese and another $36 \%$ were overweight ${ }^{(1)}$. The metabolic syndrome (MetS) describes a collection of risk factors including obesity, insulin resistance, hypertension and abnormal lipid profiles that are associated with an increased risk of type 2 diabetes (T2D) and $\mathrm{CVD}^{(2,3)}$. While there is, as yet, no universally accepted definition for the MetS, the International Diabetes Federation has proposed diagnostic criteria that are in widespread clinical use ${ }^{(4)}$. The five common features for all definitions are: obesity (greater body weight, BMI and/or waist circumference), elevated glucose and insulin levels, reduced HDL-cholesterol, elevated TAG and elevated blood pressure.

Identifying individuals with MetS risk factors and intervening at an early stage may help prevent the development of T2D, CVD and other associated chronic diseases ${ }^{(5)}$. Because obesity is a major cause of the MetS, weight loss is recommended for all overweight and obese adults with the syndrome or T2D by increasing physical activity and reducing energy intake ${ }^{(6)}$. Weight loss combined with an exercise programme can delay and possibly prevent the development of the MetS and T2D in insulin-resistant individuals ${ }^{(4,5,7)}$. For instance, a subset of 3234 participants began lifestyle modifications through the Diabetes Prevention Program with a goal of more than $7 \%$ weight loss and $150 \mathrm{~min}$ of physical activity/week $^{(8)}$. The ideal hypoenergetic diet should not only decrease body weight, but also decrease body fat while sparing lean tissue and improving MetS risk factors. However, the optimal dietary macronutrient composition of protein, carbohydrate and fat that facilitates lasting and safe weight loss is more controversial.

A low-fat diet containing $20-30 \%$ fat, $55-70 \%$ carbohydrate and $15-20 \%$ protein has been recommended by various health organisations, such as the American Heart Association, as the traditional approach for weight loss, primarily based on the assumption that excess dietary fat is primarily responsible for obesity. Yet, the obesity epidemic persists and MetS prevalence has actually increased over the same time frame as dietary fat intake has decreased ${ }^{(9)}$. We recently completed a study examining the effects of a highprotein, low-fat, low-carbohydrate diet with and without exercise, on risk factors associated with CVD and the MetS

Abbreviations: bpm, beats/min; HP, high protein group; LP, low protein group; MetS, metabolic syndrome; NP, normal protein group; T2D, type 2 diabetes. 
in overweight women ${ }^{(10)}$. We showed that the high-protein diet ( $1 \mathrm{~g}$ protein: $1 \mathrm{~g}$ carbohydrate) was superior to a low-fat, high-carbohydrate diet ( $1 \mathrm{~g}$ protein: $3 \mathrm{~g}$ carbohydrate) either alone, or when combined with exercise, in promoting weight loss, preserving lean mass and improving body composition. During that study, the subjects on the high-protein diet reported some difficulty with compliance and a lack of variety in food choices. In the present study, we examined whether a normal level of protein $(1 \mathrm{~g}$ protein: $2 \mathrm{~g}$ carbohydrate) could provide the same benefits as a high-protein diet while increasing food choices and thereby promoting better compliance. We also wanted to examine whether there was a dose-response to the protein:carbohydrate ratio and if so, what the nature of this relationship was for the various outcomes associated with MetS and CVD risk. We hypothesised that the combined effects of a normal protein: carbohydrate ratio with cardiovascular and resistance training would be more beneficial and easier to comply with than either the low- or high-protein diets in this target population of women with risk factors for the MetS.

\section{Materials and methods}

\section{Study design}

Overweight women were recruited and randomly assigned to one of three experimental diets, all restricted in energy (approximately 30\%) and at most 30\% of energy from fat. The diets differed in the ratio of protein:carbohdyrate - low protein (LP, $1 \mathrm{~g}$ protein: $4 \mathrm{~g}$ carbohydrate); normal protein (NP, $1 \mathrm{~g}$ protein: $2 \mathrm{~g}$ carbohydrate); high protein (HP, $1 \mathrm{~g}$ protein: $1 \mathrm{~g}$ carbohydrate). Subjects followed the diets for 12 weeks during which they also participated in an obligatory exercise regimen.

\section{Subject recruitment and screening}

The study was conducted according to the guidelines laid down in the Declaration of Helsinki and all procedures involving human subjects were approved by the Research Ethics Board of the University of Guelph. Written informed consent was obtained from all subjects. Female subjects were recruited between January and August and had staggered entry from April to November 2004. Of the 300 potential subjects, 149 met with the study coordinator for eligibility screening and an information session. Inclusion criteria were female sex, age 18-60 years, plus any three risk factors for the MetS. Risk factors included: BMI $>27 \mathrm{~kg} / \mathrm{m}^{2}$; waist circumference $>88 \mathrm{~cm}$; blood pressure $>130 / 85 \mathrm{mmHg}$; fasting blood glucose $>6.1 \mathrm{mmol} / \mathrm{l}$; fasting TAG $>1.7 \mathrm{mmol} / \mathrm{l}$; a fasting HDL-cholesterol below $1.29 \mathrm{mmol} / \mathrm{l}$. Exclusion criteria were: medication; dietary or herbal supplement use known to affect blood glucose; blood lipids; blood pressure; protein metabolism or body weight; pre-existing diabetes; renal dysfunction; CVD; or thyroid disorders.

At the screening session, height was measured in the standing position using a metric scale to the nearest $0.5 \mathrm{~cm}$ without footwear. Body weight was measured without footwear and in light clothing using either a digital scale accurate to $0.01 \mathrm{~kg}$ (for subjects under $100 \mathrm{~kg}$, Acculab SV-100; Acculab-Sartorius Group) or a mechanical balance beam scale accurate to $0.3 \mathrm{~kg}$ (subjects over $100 \mathrm{~kg}$, Health o meter 400KL; Healthometerregistered). BMI was calculated for each subject as weight $(\mathrm{kg}) /$ height $(\mathrm{m})^{2}$. Waist circumference was measured to the nearest $0.5 \mathrm{~cm}$ using a flexible tape measure at the lateral level of the twelfth or lower floating rib. Hip circumference was estimated at the fullest part of the buttocks. Blood pressure and heart rate were measured in the seated position after a 5 min rest period using a standard digital sphygmomanometer (Lifesource). Measurements were taken on the left arm in duplicate and averaged. If subjects 'qualified' at this point, then blood was not collected until study entry. If subjects did not meet the entry criteria, then a fasting fingerprick blood sample was taken to measure glucose and blood lipids using a Cholestech LDX $^{\circledR}$ cassette measurement system. All subjects who qualified provided a signed consent form and their doctor's permission to participate.

\section{Body composition}

Body composition was measured at baseline, week 6 and week 12 in subjects using bioelectrical impedance analysis (BodyStat $1500^{\mathrm{TM}}$; BodyStat, Inc.) in light clothing immediately after voiding their bladders, as we have previously described $^{(11)}$. Subjects were asked to refrain from alcohol, caffeine and strenuous exercise for $12 \mathrm{~h}$ before the measurements, and to consume $0 \cdot 5-1$ litre of water in this same $12 \mathrm{~h}$ period.

\section{Urine collection and analyses}

At baseline and week 12, two complete $24 \mathrm{~h}$ urine samples were collected. Subjects were instructed to maintain their habitual diet and experimental diet at baseline and week 12 collections, respectively. No alcohol was permitted for $24 \mathrm{~h}$ before or during the collection, and samples were not collected during menstruation. Subjects were provided with pre-labelled, amber-coloured, 3-litre urine collection containers, 1-litre collection bottles and a voiding container (urine hat). On the morning of collection, subjects did not collect their first void of the morning, but did write down the time on the 3 -litre container. All voids for the next $24 \mathrm{~h}$ were collected into the voiding container and carefully poured into the 3-litre container. The 1-litre container was used to facilitate voids collected away from home, and all urine was poured into the 3-litre container before the bottles were returned. The last void was collected after $24 \mathrm{~h}$ on the second morning at the same time as the first collection. This ending time was recorded on the 3-litre container. Urine collection containers were refrigerated at all times, and samples were immediately brought to the Human Nutraceutical Research Unit on the second morning. The total volume of urine was then recorded by a study coordinator. The $24 \mathrm{~h}$ urine collection was gently mixed, and then divided into aliquots into three $15 \mathrm{ml}$ polypropylene tubes, frozen at $-20^{\circ} \mathrm{C}$ until analysis and the remainder discarded. 


\section{Creatinine}

To evaluate completeness of the $24 \mathrm{~h}$ urine collections, urinary creatinine levels were measured. All $24 \mathrm{~h}$ urine samples were analysed for creatinine by MDS Laboratory Services using an alkaline picrate method on a Roche Integra 800. A study coordinator provided MDS Laboratory Services with the total $24 \mathrm{~h}$ urine collection volumes of all subjects to allow for the calculation of creatinine: $24 \mathrm{~h}$ creatinine $(\mathrm{mmol} / \mathrm{l}$ per $\mathrm{d})=$ urine creatinine sample $\times$ total $24 \mathrm{~h}$ urine collection volume.

\section{Nitrogen balance}

Nitrogen balance was determined in the present study using the following equation: nitrogen balance $=$ nitrogen intake $(\mathrm{g} / \mathrm{d})-$ nitrogen output $(\mathrm{g} / \mathrm{d})$. Total nitrogen was calculated by dividing the protein content by $6 \cdot 25$, as protein is $16 \%$ nitrogen. Nitrogen intake was estimated from the total dietary protein intake as assessed from the analysed food records (as described above). Nitrogen output was calculated as $24 \mathrm{~h}$ total urinary nitrogen plus one-tenth of the overall average nitrogen intake ( $1.3 \mathrm{~g}$ in the present study) to account for normal losses via stool, skin, hair and other losses. Urinary nitrogen was analysed from $24 \mathrm{~h}$ urine samples in duplicate using a Kjeltec Auto 1030 Analyzer (Tecator). Casein, soyabean and a subject reference sample were used as standards. The percentage of nitrogen in urinary samples was calculated using the following equation:

$$
\begin{aligned}
\text { Nitrogen }(\%)= & (14.01 \times 0 \cdot 1) \times(\text { titrant volume }(\mathrm{ml}) \\
& - \text { blank volume }(\mathrm{ml})) / \text { sample weight }(\mathrm{mg}),
\end{aligned}
$$

where 14.01 is the atomic weight of nitrogen and $0 \cdot 1$ is the molarity of titrant acid. The amount of nitrogen in the total $24 \mathrm{~h}$ urine volume was then calculated using the following equation:

$$
\begin{aligned}
& \text { Nitrogen in total } 24 \mathrm{~h} \text { urine volume }(\mathrm{g}) \\
& \quad=\text { total } 24 \mathrm{~h} \text { urine volume }(\mathrm{ml}) \times \text { nitrogen }(\%) .
\end{aligned}
$$

\section{Study orientation and counselling}

Study orientation sessions were led by study coordinators and provided subjects with a handbook that included administration, exercise and food sections. Details of the study design, contact personnel, and details for completing food records, food composition tables, how to complete the workout sessions, logs for diet, exercise, medication use and side effects and directions for preparing for study visits and measurements were provided in this handbook. Catalogues of recipes, sample menus and an online newsletter provided additional resources for the study subjects. Once $7 \mathrm{~d}$ habitual food records were analysed, subjects were randomised into the diet groups. Once they had started the intervention, they met weekly with a study supervisor for counselling, assessment of compliance and anthropometric measurements.

\section{Diet and exercise protocols}

Of the 149 potential subjects screened, 117 met the eligibility criteria and were randomised to one of the three experimental diets. All subjects were assigned to the exercise portion of the intervention. Of these, fifty-four completed the 12-week nutrition and exercise intervention study. Daily food records were recorded by the subjects each day during the intervention period. Diet records were analysed at baseline and periodically over the intervention period using Food Processor for Windows 1998 (version 7.11; ESHA Research). During the intervention period, subjects also recorded the amount of protein and carbohydrate consumed (in g) to assist with compliance to their assigned diet. The energy intake of all experimental diets was reduced approximately $30 \%$ relative to the baseline data for each subject based on the data collected from $7 \mathrm{~d}$ habitual food records. Subjects were also counselled to consume no more than $30 \%$ of energy as fat. Subjects were encouraged to consume whole foods as opposed to pre-packaged or processed foods and to restrict intake of whole-fat dairy, high-fat red meats, deep-fried foods, potato chips, cookies and refined sugar products. Instead, subjects were encouraged to choose whole-grain products, lower-fat meats, fish, turkey, eggs, low-fat milk and cottage cheese, nuts, seeds, and a variety of vegetables, fruits and berries.

Before beginning the study workout programme, subjects completed baseline fitness testing to assess muscular strength and cardiovascular fitness. These tests were repeated at week 12 to compare changes in fitness. Subjects were instructed to wear workout clothes and running shoes to their scheduled appointments. A small snack was recommended $2 \mathrm{~h}$ before appointment times, but nothing afterwards to ensure proper digestion and energy levels. No alcohol or exercise was permitted $6 \mathrm{~h}$ before testing, and caffeine and smoking not permitted within $2 \mathrm{~h}$ of the testing time. All fitness testing was completed at the University of Guelph Athletic Centre under the supervision of a certified fitness consultant. Given that the majority of subjects had low fitness levels at baseline, a modified 1 repetition maximum strength test was used to reduce the risk of injury during the test period ${ }^{(12)}$ using the same order of testing on each resistance machine ${ }^{(13)}$. Muscular endurance was measured using the modified Canadian aerobic fitness test developed by the Canadian Society of Exercise Physiology ${ }^{(14)}$ while the subject wore a chest heart rate monitor (Polar Electro ${ }^{\mathrm{TM}}$ ).

All subjects participated in a 12 -week circuit training programme at the University of Guelph Athletic Centre as part of the study. The $1 \mathrm{~h}$ study fitness programme was completed three times/week on Mondays, Wednesdays and Fridays at a consistent time assigned to each subject. Subjects had to sign in for their workout sessions, and all exercises were supervised by a study coordinator and/or personal trainer. Subjects began their workout with a 9 min warm-up using springboard pads where walking in place, jogging or dancing took place. Then, subjects completed a 30 min circuit alternating between resistance training and cardiovascular exercise bouts. All main muscle groups of the body were targeted throughout the thirteen resistance training machines. Starting weight values on resistance training equipment were $65 \%$ of their calculated maximum strength as determined by their modified 1 repetition maximum. Subjects were instructed to 
complete one set of eight to fifteen repetitions on each piece of equipment to reach muscle fatigue. When subjects could complete fifteen repetitions on any given machine, the next bar of weight was added (approximately 5\% increase) to ensure maximum intensity. At each workout, subjects recorded the weight load used and the number of repetitions performed on each piece of equipment in their circuit training logs. The aerobic stations alternated between a step, springboard pad and stationary bike. Following the circuit, subjects completed abdominal exercises until fatigue including a standard crunch, oblique crunch and a core-strengthening exercise called the plank, on exercise mats. Subjects then concluded their workout with a flexibility routine by stretching all main muscle groups using stretches provided in their study manual to reduce muscle soreness and injury.

Subjects began exercising at $65 \%$ of their maximum heart rate for the first 3 weeks and gradually increased the intensity by $5 \%$ every 3 weeks to a maximum intensity of $80 \%$ by week 12. Target heart rates were determined using the Karvonen formula:

$$
\begin{aligned}
\text { Target heart rate }(\mathrm{bpm})= & ((\text { maximum heart rate }(\mathrm{bpm}) \\
& - \text { age }(\text { years }) \\
& - \text { resting heart rate }(\mathrm{bpm})) \\
& \times(\text { desired intensity })) \\
& + \text { resting heart rate }(\mathrm{bpm})
\end{aligned}
$$

with the maximum heart rate being 226 beats/min (bpm) and the desired intensity being $65,70,75$ or $80 \%$ depending on week of participation and resting heart rate as measured weekly by a study coordinator ${ }^{(15)}$. To ensure that subjects were exercising at the appropriate intensity, exercising heart rates were taken midway through each workout and recorded on their circuit training logs. Gym supervisors compared their actual exercising heart rates with their target heart rates, and offered feedback to ensure the appropriate intensity was attained at each session.

\section{Statistical analysis}

Subjects who did not complete the entire 12-week study period were excluded from the final analysis and reported as dropouts. The final analysis was thus carried out on those fiftyfour subjects who completed the entire 12 weeks of the study. Of these subjects, three subjects (two from the LP group and one from the HP group) were not included in the statistical analysis of dietary and related measures (i.e. nitrogen balance) because these subjects failed to submit their completed dietary records at the end of the study. All data are presented as means with their standard errors. Statistical analysis was performed using SPSS 12.0 for Windows (SPSS, Inc.). Age was used as a covariate to determine whether age played a role in the statistical model. A log transformation was used for some diet composition data as well as nitrogen excretion and balance data to comply with the normality and equal variance assumptions of the statistical analyses. A one-sample $t$ test was used to compare dietary protein intake levels consumed in the study with the RDA of $0.8 \mathrm{~g} / \mathrm{kg}$ per $\mathrm{d}$.
Baseline measurements were assessed using a univariate ANOVA with diet as the fixed factor to determine whether there were differences between the three diet groups before the intervention commenced. If baseline measures were significantly different, three separate paired $t$ tests were performed to examine the differences between baseline and week 12 within a diet, while three separate univariate ANOVA with week as the fixed factor were performed to examine differences between baseline, week 6 and week 12 within a diet. If baseline measures were not significantly different, the effects of the 12-week intervention study were assessed using a univariate ANOVA, with the dependent variable measured as the within-subject factor and diet and week as the between-subject factors. The following variables were assessed by examining the overall change in the 12-week intervention as opposed to the beginning and ending values: total body weight; BMI; waist circumference; waist:hip ratio; body composition measures; nitrogen balance. This approach was used since the change over 12 weeks of these measurements was more valuable for discussion purposes than the absolute values which were the more critical numbers for the remaining study variables. If an interaction was noted, post hoc subgroup analysis was performed using Tukey's test. Differences were considered significant if $P<0 \cdot 05$.

\section{Results}

\section{Subject flowthrough}

The recruitment and flowthrough of subjects during the recruitment and intervention period are shown in Fig. 1. A total of sixty-three subjects who were eligible for the study based on their in-person screening did not complete the study. Of these sixty-three subjects, twenty-eight completed none or some of the baseline measures, but did not begin the study protocol: ten of these subjects felt they could no longer commit to the large time requirement of the study; six stopped returning telephone calls and showing up for appointments; four reported an illness or death in their family; three did not comply with the study protocol (including not following instructions before or during baseline measures); three suffered from personal illness or injury during this time frame; two had irreconcilable scheduling difficulties.

A total of eighty-nine subjects began the 12-week intervention and thirty-five of these subjects did not complete the entire study protocol. Overall, the main reasons for dropping out of the study included non-compliance with the study protocol and no longer returning telephone calls or showing up for appointments. Specifically, twelve, ten and thirteen subjects dropped out from the LP, NP and HP groups, respectively. Most of these subjects dropped out before the 8-week time point. Additional recruitment efforts for alternate entry points were not successful, and therefore fifty-four subjects completed all 12 weeks.

\section{Reported adverse events}

Reported adverse events were few in the present study. Approximately half of the subjects reported feeling lethargic 


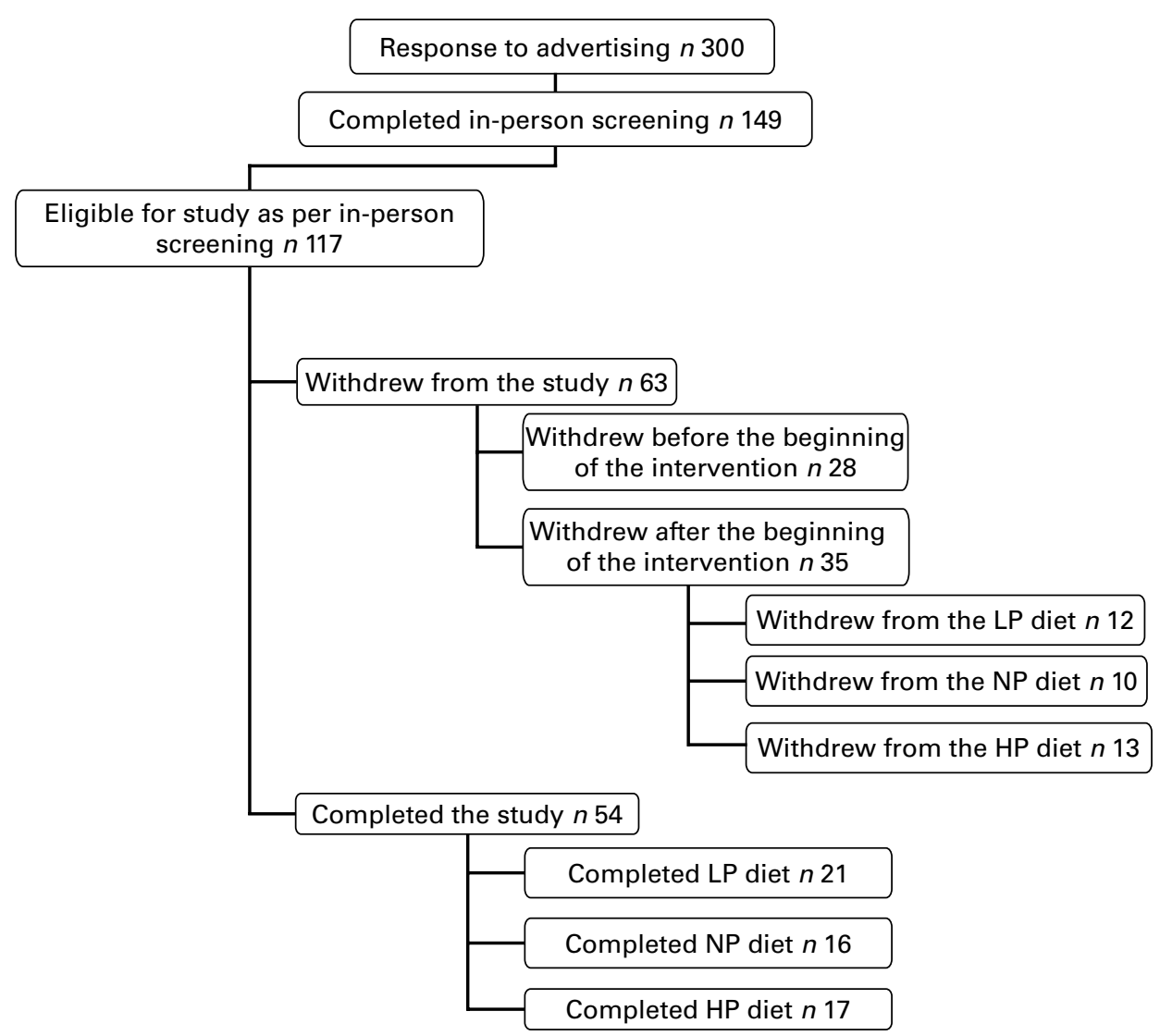

Fig. 1. Study design and flowthrough of the study subjects from advertisement through to the end of the 12-week intervention. LP, low protein group; NP, normal protein group; HP, high protein group.

during the first few days of the study, but could still complete their scheduled workout sessions. All reported feeling well for the remainder of the study, and many recorded that they had more energy and felt better than before the study began. However, three subjects complained of constipation during the first or second week of the study, which resolved when they began drinking more water throughout the day. Only one subject in the LP group reported loss of some scalp hair after the study was completed.

\section{Changes in anthropometry, blood pressure and heart rate}

The details of the baseline and week 12 characteristics for subjects who completed the entire study are shown in Table 1. There were no significant differences in any of the anthropometric variables between the three diet groups at baseline. After 12 weeks, all diet groups had lost significant $(P<0.05)$ body weight. Although the NP group appeared to lose more weight than the LP group, this difference was not significant $(P=0.07)$. Thus, the weight losses were $6 \cdot 2,8.9$ and $7 \cdot 1 \mathrm{~kg}$ for the LP, NP and HP groups, respectively. The patterns of weight loss over time were similar between the three groups (data not shown). BMI decreased $(P<0.05)$ in all diet groups similarly. Of the fifty-four subjects, fifty-three (98\%) had BMI $>27 \mathrm{~kg} / \mathrm{m}^{2}$ at baseline compared with forty-six (85\%) at week 12. The one subject who did not have a BMI $>27 \mathrm{~kg} /$ $\mathrm{m}^{2}$ at baseline had a body fat percentage $>30 \%$.
After 12 weeks, there were significant decreases in body fat in all diet groups. The NP group lost more total body fat and body fat as a percentage of body weight than the LP group $(P<0.01)$, and more body fat as a percentage of body weight than the HP group $(P<0.05)$. Only the LP group had a significant loss of lean mass of $1.5 \mathrm{~kg}(P<0.05)$ at the 12 week time point. However, as a percentage of total body weight, all of the groups experienced an increase in lean mass over the 12-week diet and exercise intervention of $2 \cdot 4$, 5.6 and $3.9 \%$ in the LP, NP and HP groups, respectively. This increase was significantly greater in the NP group than in the LP group $(P<0.05)$.

Abdominal obesity, as estimated by waist circumference, decreased significantly $(P<0.05)$ by $7.9,11.6$ and $8.6 \mathrm{~cm}$ in the LP, NP and HP groups, respectively. Again, the decrease in the NP group was greater than that in the LP group. Furthermore, hip circumferences decreased similarly $(P<0.05)$ in response to each diet with reductions of $7.4,8.8$ and $8.4 \mathrm{~cm}$ in the LP, NP and HP groups, respectively (Table 1). Waist:hip ratios declined significantly $(P<0.05)$ after 12 weeks by 0.01 , 0.04 and 0.01 in the LP, NP and HP groups, respectively, but reductions were greater in the NP $v$ LP $(P=0.020)$ and HP $(P=0 \cdot 025)$ groups.

The group results indicated that all three diets reduced systolic blood pressure $(P<0.05)$ by $8.7,8.1$ and $10.6 \mathrm{mmHg}$ and diastolic blood pressure $(P<0.05)$ by $5.4,5.7$ and $5.0 \mathrm{mmHg}$ in the LP, NP and HP groups, respectively, but there were no 
Table 1. Baseline (BL) and week 12 (12 wk) characteristics of the study population

(Mean values with their standard errors)

\begin{tabular}{|c|c|c|c|c|c|c|c|c|c|c|c|c|}
\hline & \multicolumn{4}{|c|}{ LP } & \multicolumn{4}{|c|}{ NP } & \multicolumn{4}{|c|}{$\mathrm{HP}$} \\
\hline & $\mathrm{BL}$ & SEM & $12 \mathrm{wk}$ & SEM & $\mathrm{BL}$ & SEM & $12 \mathrm{wk}$ & SEM & $\mathrm{BL}$ & SEM & $12 \mathrm{wk}$ & SEM \\
\hline Subjects $(n)$ & \multicolumn{4}{|c|}{21} & \multicolumn{4}{|c|}{16} & \multicolumn{4}{|c|}{17} \\
\hline Age (years) & $41 \cdot 1^{a}$ & $2 \cdot 3$ & & & $39.9^{a}$ & $2 \cdot 7$ & & & $39 \cdot 4^{\mathrm{a}}$ & $2 \cdot 7$ & & \\
\hline Age range (years) & $18-54$ & & & & $24-55$ & & & & $21-56$ & & & \\
\hline Height $(\mathrm{cm})$ & $166 \cdot 5^{\mathrm{a}}$ & 1.5 & & & $165 \cdot 2^{\mathrm{a}}$ & 1.6 & & & $164 \cdot 4^{\mathrm{a}}$ & 1.8 & & \\
\hline Height range $(\mathrm{cm})$ & $154-178$ & & & & $151 \cdot 0-177 \cdot 5$ & & & & $149 \cdot 0-174 \cdot 0$ & & & \\
\hline BMI $\left(\mathrm{kg} / \mathrm{m}^{2}\right)$ & $34 \cdot 6^{\mathrm{a}}$ & $1 \cdot 3$ & $32 \cdot 3^{\mathrm{b}}$ & 1.3 & $35 \cdot 8^{a}$ & $1 \cdot 2$ & $32.5^{\mathrm{b}}$ & $1 \cdot 1$ & $36 \cdot 3^{\mathrm{a}}$ & 1.6 & $33 \cdot 7^{\mathrm{b}}$ & 1.5 \\
\hline BMI range $\left(\mathrm{kg} / \mathrm{m}^{2}\right)$ & $28 \cdot 1-52 \cdot 4$ & & $25 \cdot 2-49 \cdot 2$ & & $27 \cdot 2-43 \cdot 8$ & & $24 \cdot 1-39 \cdot 2$ & & $26 \cdot 4-49 \cdot 3$ & & $25 \cdot 4-43 \cdot 1$ & \\
\hline Total weight $(\mathrm{kg})$ & $96 \cdot 3^{\mathrm{a}}$ & 4.6 & $90 \cdot 2^{b}$ & 4.5 & $98.0^{\mathrm{a}}$ & 4.1 & $89 \cdot 1^{\mathrm{b}}$ & 3 & $98.0^{\mathrm{a}}$ & 4.4 & $90 \cdot 9^{\mathrm{b}}$ & 4.3 \\
\hline Fat weight $(\mathrm{kg})$ & $41.5^{\mathrm{a}}$ & $3 \cdot 0$ & $36 \cdot 8^{b}$ & 2.9 & $43 \cdot 6^{a}$ & $2 \cdot 7$ & $34.9^{c}$ & $2 \cdot 6$ & $44.9^{\mathrm{a}}$ & 3.4 & $38 \cdot 2^{b c}$ & $3 \cdot 2$ \\
\hline Fat weight (\%) & $42 \cdot 3^{\mathrm{a}}$ & $1 \cdot 1$ & $39.9^{b}$ & $1 \cdot 2$ & $44.0^{\mathrm{a}}$ & $1 \cdot 2$ & $38.4^{\mathrm{C}}$ & 1.5 & $44 \cdot 9^{\mathrm{a}}$ & 1.7 & $41 \cdot 0^{\mathrm{b}}$ & 1.8 \\
\hline Lean weight $(\mathrm{kg})$ & $54.9^{\mathrm{a}}$ & 1.8 & $53.4^{b}$ & 1.8 & $54.4^{\mathrm{a}}$ & 1.8 & $54 \cdot 2^{\mathrm{a}}$ & 1.6 & $53 \cdot 2^{\mathrm{a}}$ & 1.6 & $52 \cdot 8^{\mathrm{ab}}$ & 1.7 \\
\hline Lean weight (\%) & $57 \cdot 7^{\mathrm{a}}$ & $1 \cdot 1$ & $60 \cdot 1^{b}$ & $1 \cdot 2$ & $56 \cdot 0^{\mathrm{a}}$ & $1 \cdot 2$ & $61 \cdot 6^{c}$ & 1.5 & $55 \cdot 1^{a}$ & 1.7 & $59 \cdot 0^{\mathrm{b}}$ & $1 \cdot 8$ \\
\hline Waist circumference $(\mathrm{cm})$ & $102 \cdot 6^{\mathrm{a}}$ & $2 \cdot 1$ & $94.8^{b}$ & $2 \cdot 4$ & $105 \cdot 5^{a}$ & $2 \cdot 9$ & $93 \cdot 9^{\mathrm{c}}$ & 2.9 & $104 \cdot 4^{\mathrm{a}}$ & $2 \cdot 3$ & $95 \cdot 9^{\mathrm{bc}}$ & $2 \cdot 4$ \\
\hline Hip circumference $(\mathrm{cm})$ & $122 \cdot 8^{\mathrm{a}}$ & $2 \cdot 2$ & $115 \cdot 4^{\mathrm{b}}$ & $2 \cdot 6$ & $126 \cdot 5^{\mathrm{a}}$ & $2 \cdot 8$ & $117 \cdot 7^{\mathrm{b}}$ & 2.9 & $127 \cdot 2^{\mathrm{a}}$ & 3.3 & $118 \cdot 8^{\mathrm{b}}$ & 3.3 \\
\hline Waist:hip ratio & $0.84^{\mathrm{a}}$ & 0.01 & $0.82^{\mathrm{b}}$ & 0.01 & $0.83^{\mathrm{a}}$ & 0.01 & $0.80^{c}$ & 0.01 & $0.82^{\mathrm{a}}$ & 0.02 & $0.81^{\mathrm{b}}$ & 0.02 \\
\hline Systolic BP (mmHg) & $130 \cdot 5^{\mathrm{a}}$ & $3 \cdot 0$ & $121 \cdot 8^{\mathrm{b}}$ & 2.9 & $128 \cdot 0^{\mathrm{a}}$ & 3.5 & $119.9^{b}$ & $3 \cdot 2$ & $132.9^{a}$ & 4.0 & $122 \cdot 4^{\mathrm{b}}$ & $2 \cdot 6$ \\
\hline Diastolic BP (mmHg) & $80 \cdot 4^{\mathrm{a}}$ & 1.6 & $75 \cdot 0^{\mathrm{b}}$ & 1.6 & $78.9^{\mathrm{a}}$ & $2 \cdot 2$ & $73 \cdot 2^{b}$ & 1.9 & $80 \cdot 5^{\mathrm{a}}$ & 2.4 & $75 \cdot 4^{b}$ & 1.7 \\
\hline Resting heart rate (bpm) & $75 \cdot 7^{\mathrm{a}}$ & $1 \cdot 8$ & $70 \cdot 2^{b}$ & $1 \cdot 2$ & $79 \cdot 3^{\mathrm{a}}$ & $2 \cdot 7$ & $66 \cdot 3^{\mathrm{b}}$ & 1.4 & $80 \cdot 5^{\mathrm{a}}$ & 1.6 & $71 \cdot 7^{\mathrm{b}}$ & $1 \cdot 6$ \\
\hline
\end{tabular}

LP, low protein group; NP, normal protein group; HP, high protein group; BP, blood pressure; bpm, beats/min

a,b,c Mean values within a row with unlike superscript letters were significantly different $(P<0.05$; ANOVA followed by Tukey's post hoc test). 
significant diet effects (Table 1). After 12 weeks, resting heart rate decreased $(P<0 \cdot 0001)$ in all groups, but was unaffected by macronutrient composition. Reductions in resting heart rates were $5.6,13.0$ and $8.8 \mathrm{bpm}$ in the LP, NP and $\mathrm{HP}$ groups, respectively.

According to the MetS definition set by the International Diabetes Federation and National Cholesterol Education Adult Treatment Panel III ${ }^{(16)}$, thirty-six (67\%) and twentyeight $(52 \%)$ subjects would have been diagnosed with the MetS at baseline compared with seventeen (32\%) and ten (19\%) subjects at week 12 (Fig. 2). Our inclusion criteria differed in that we considered BMI and waist circumference as two separate risk factors, whereas these are a single risk factor in these other two definitions.

\section{Experimental diet composition and consumption patterns}

Macro- and micronutrient compositions of the baseline habitual and the LP, NP and HP groups at weeks 6 and 12, as recorded in the daily food records, are shown in Table 2. Since these interventions were designed to promote weight loss, each dietary group had reduced energy intake at weeks 6 and $12 \quad(P<0 \cdot 001)$ compared with the habitual diets. Reductions in energy intake over the 12 -week period were similar in each group with decreases of 3641, 3729 and $3633 \mathrm{~kJ} / \mathrm{d}$ in the LP, NP and HP groups, respectively. This corresponds to an average energy reduction of $40 \cdot 1 \%$.

The LP, NP and HP groups consumed protein and carbohydrate in the ratios of $1: 3 \cdot 5,1: 3 \cdot 2$ and $1: 3 \cdot 2$ at baseline and $1: 3 \cdot 5,1: 2 \cdot 1$ and $1: 1 \cdot 3$ by week 12 , respectively. Subjects assigned to the LP and HP groups reported some difficulty

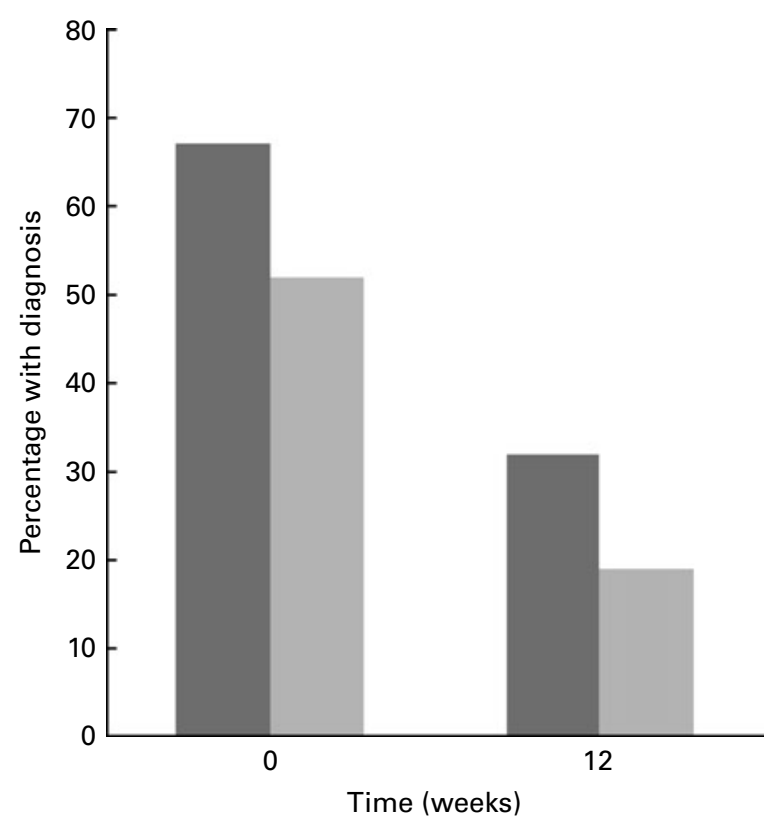

Fig. 2. Percentage of subjects who completed the 12-week intervention study who would be diagnosed with the metabolic syndrome according to the definition set by the International Diabetes Federation $(\square)$ and National Cholesterol Education Adult Treatment Panel III ( $\square$ ). Week 0 corresponds to baseline values. in meeting the protein:carbohydrate ratios of $1: 4$ and $1: 1$, respectively, while the NP group was mostly content with their macronutrient composition goals. Protein intake decreased significantly $(P<0 \cdot 001)$ over the 12 weeks from 82 and $88 \mathrm{~g} / \mathrm{d}$ to 55 and $75 \mathrm{~g} / \mathrm{d}$ in the LP and NP groups, respectively, and increased significantly $(P<0.001)$ in the HP group from 84 to $100 \mathrm{~g} / \mathrm{d}$. Changes in the percentage of protein intake were not significant for the LP group at week 12, but did increase $(P<0.001)$ to 23 and $31 \%$ in the NP and HP groups, respectively. All three dietary groups were significantly different $(P<0.001)$ in terms of protein intake at both weeks 6 and 12 . Of the subjects, fifteen (71\%), twelve (75\%) and ten (59\%) consumed at least the RDA of $0.8 \mathrm{~g} / \mathrm{kg}$ per $\mathrm{d}$ at baseline compared with three (14\%), eleven (69\%) and thirteen (76\%) at week 12 in the LP, NP and HP groups, respectively. By week 12, the LP group's average protein consumption $(\mathrm{g} / \mathrm{kg}$ per $\mathrm{d})$ was significantly less $(P<0.05)$ than the RDA of $0.8 \mathrm{~g} / \mathrm{kg}$ per $\mathrm{d}$, the NP group's protein consumption ( $\mathrm{g} / \mathrm{kg}$ per $\mathrm{d}$ ) was similar to the RDA and the HP group's protein consumption ( $\mathrm{g} / \mathrm{kg}$ per $\mathrm{d}$ ) was significantly higher $(P<0.05)$ than the RDA.

In addition, carbohydrate intake decreased significantly $(P<0.001)$ over the 12 weeks in all of the diet groups. Changes in the percentage of carbohydrate intake were not significant for the NP group at week 12, but increased $(P<0.001)$ to $58 \%$ in the LP group and decreased to $39 \%$ in the HP group. Total sugar intake decreased $(P<0 \cdot 001)$ in all groups, but decreased the most in the HP group. All groups reduced their total fat intake $(P<0.001)$ similarly, resulting in a net decrease in the percentage of energy from fat to 26,29 and $30 \%$ in the LP, NP and HP groups, respectively. The intake of several micronutrients was altered by the interventions. Changes unique to the LP diet were small decreases in vitamin $\mathrm{B}_{12}$ and thiamin intake. Sodium intake decreased significantly $(P<0 \cdot 001)$ in all groups, but decreases were greater in the LP and NP groups $v$ the HP group. Although there were no significant changes in $\mathrm{Ca}, \mathrm{Zn}$ or vitamin $\mathrm{D}$ intake among the HP subjects, both the LP and NP groups reported significant decreases $(P<0.05)$ by week 12 . In particular, Ca intake decreased by 282 and $138 \mathrm{mg} / \mathrm{d}$ in the LP and NP groups, respectively. Also, both the LP and NP groups reported $\mathrm{Zn}$ reductions of 2.7 and $2.2 \mathrm{mg} / \mathrm{d}$ and vitamin $\mathrm{D}$ reductions of 57 and $47 \mathrm{IU}$, respectively. Riboflavin intake increased $(P<0.05)$ in the HP group, while it decreased in the LP and NP groups. Niacin intake increased $(P<0.05)$ only in the HP group; there were no changes in niacin intake in either the LP or NP group. There were significant decreases in caffeine consumption for all groups $(P<0.05)$ and no changes in alcohol consumption (data not shown).

\section{Changes in fitness}

Compliance to the study fitness programme was very good among the subjects in all the dietary groups. Of the thirty-six prescribed exercise sessions, subjects attended, on average, thirty-two (90\%) of these sessions. The group results indicated that all three diet groups had increases in maximal muscle strength on all thirteen resistance training machines after 
Table 2. Diet composition of baseline (BL) habitual and the experimental diets at week 12 (12 wk) (Mean values with their standard errors)

\begin{tabular}{|c|c|c|c|c|c|c|c|c|c|c|c|c|}
\hline & \multicolumn{4}{|c|}{ LP } & \multicolumn{4}{|c|}{ NP } & \multicolumn{4}{|c|}{$\mathrm{HP}$} \\
\hline & $B L$ & SEM & $12 \mathrm{wk}$ & SEM & $\mathrm{BL}$ & SEM & $12 \mathrm{wk}$ & SEM & $\mathrm{BL}$ & SEM & $12 \mathrm{wk}$ & SEM \\
\hline Energy (kJ) & $9216^{a}$ & 567 & $5575^{b}$ & 280 & $9161^{a}$ & 639 & $5432^{b}$ & 176 & $9081^{a}$ & 506 & $5449^{b}$ & 336 \\
\hline PRO $(g)$ & $82 \cdot 2^{\mathrm{a}}$ & 3.8 & $55 \cdot 5^{\mathrm{b}}$ & 2.5 & $88 \cdot 2^{\mathrm{a}}$ & 4.5 & $74 \cdot 8^{\mathrm{c}}$ & $2 \cdot 8$ & $83 \cdot 6^{\mathrm{a}}$ & $5 \cdot 7$ & $100 \cdot 2^{d}$ & $5 \cdot 0$ \\
\hline PRO (\% energy) & $15 \cdot 6^{a}$ & 0.7 & $16 \cdot 8^{\mathrm{a}}$ & 0.6 & $16 \cdot 6^{a}$ & 0.8 & $23 \cdot 1^{\mathrm{b}}$ & 0.5 & $15 \cdot 6^{\mathrm{a}}$ & 0.8 & $31 \cdot 5^{\mathrm{c}}$ & 1.5 \\
\hline PRO ( $/ \mathrm{kg}$ per d) & $0.88^{a}$ & 0.04 & $0.63^{\mathrm{b}}$ & 0.03 & $0.91^{a}$ & 0.04 & $0.86^{a}$ & 0.05 & $0.87^{a}$ & 0.06 & $1 \cdot 15^{\mathrm{c}}$ & 0.08 \\
\hline Carbohydrate (g) & $284^{\mathrm{a}}$ & 20 & $193^{\mathrm{b}}$ & 9 & $277^{a}$ & 25 & $157^{\mathrm{c}}$ & 5 & $256^{a}$ & 16 & $127^{d}$ & 9 \\
\hline $\mathrm{CHO}$ (\% energy) & $51^{a}$ & 1 & $58^{\mathrm{b}}$ & 1 & $49^{\mathrm{a}}$ & 1 & $48^{\mathrm{a}}$ & 1 & $47^{a}$ & 2 & $39^{c}$ & 1 \\
\hline Sugar total (g) & $114^{\mathrm{a}}$ & 12 & $76^{\mathrm{b}}$ & 5 & $121^{\mathrm{a}}$ & 18 & $66^{\mathrm{b}, \mathrm{c}}$ & 5 & $97^{\mathrm{a}}$ & 11 & $59^{c}$ & 10 \\
\hline PRO:CHO ratio & \multicolumn{2}{|c|}{$1: 3 \cdot 5^{\mathrm{a}}$} & \multicolumn{2}{|c|}{$1: 3 \cdot 5^{a}$} & & & \multicolumn{2}{|c|}{$1: 2 \cdot 1^{\mathrm{b}}$} & \multicolumn{2}{|c|}{$1: 3 \cdot 2^{\mathrm{a}}$} & \multicolumn{2}{|c|}{$1: 1 \cdot 3^{\mathrm{c}}$} \\
\hline Fat (\% energy) & $32 \cdot 3^{\mathrm{a}}$ & 0.8 & $25 \cdot 9^{c}$ & 1 & $34 \cdot 1^{\mathrm{a}, \mathrm{b}}$ & 1.5 & $29 \cdot 4^{\mathrm{c}, \mathrm{d}}$ & 0.7 & $37.0^{\mathrm{b}}$ & 1.5 & $30 \cdot 1^{d}$ & 1.3 \\
\hline SFA (g) & $26 \cdot 5^{\mathrm{a}}$ & $2 \cdot 0$ & $12 \cdot 2^{\mathrm{b}}$ & 1.2 & $27 \cdot 9^{a}$ & 2.7 & $14 \cdot 2^{b, c}$ & 0.7 & $28 \cdot 9^{a}$ & 2.4 & $16 \cdot 5^{\mathrm{c}}$ & 1.4 \\
\hline MUFA (g) & $25 \cdot 6^{a}$ & $2 \cdot 2$ & $13 \cdot 1^{\mathrm{b}}$ & 1.4 & $26 \cdot 0^{\mathrm{a}}$ & 2.6 & $13 \cdot 1^{b, c}$ & 1.3 & $26 \cdot 5^{\mathrm{a}}$ & 1.7 & $16 \cdot 2^{\mathrm{C}}$ & 1.7 \\
\hline PUFA (g) & $12 \cdot 4^{\mathrm{a}}$ & 0.9 & $8 \cdot 7^{\mathrm{b}, \mathrm{c}}$ & 1.0 & $12 \cdot 0^{\mathrm{a}}$ & 1.4 & $6 \cdot 7^{b}$ & 0.5 & $13 \cdot 8^{\mathrm{a}}$ & 1.2 & $10 \cdot 4^{c}$ & 1.7 \\
\hline$n-3$ PUFA (g) & $0.96^{a}$ & 0.09 & $0.64^{b}$ & 0.08 & $0.83^{a}$ & 0.10 & $0.69^{b}$ & 0.09 & $1 \cdot 15^{\mathrm{a}}$ & 0.23 & $0 \cdot 82^{b}$ & 0.18 \\
\hline$n-6$ PUFA (g) & $9 \cdot 0^{\mathrm{a}}$ & 0.8 & $6 \cdot 7^{\mathrm{b}, \mathrm{c}}$ & 0.8 & $7.5^{a}$ & 0.8 & $4 \cdot 8^{\mathrm{b}}$ & 0.4 & $9 \cdot 1^{\mathrm{a}}$ & 1.0 & $8.0^{c}$ & 1.6 \\
\hline Cholesterol (mg) & $249^{a}$ & 20 & $135^{\mathrm{b}}$ & 13 & $288^{a}$ & 25 & $222^{\mathrm{a}}$ & 16 & $280^{a}$ & 22 & $321^{a}$ & 33 \\
\hline $\operatorname{Trans}(\mathrm{g})^{*}$ & $1.8^{\mathrm{a}}$ & 0.4 & $1.0^{\mathrm{b}}$ & 0.3 & $2 \cdot 3^{\mathrm{a}}$ & 0.5 & $1 \cdot 1^{\mathrm{b}}$ & 0.4 & $1.8^{\mathrm{a}}$ & 0.5 & $2 \cdot 6^{\mathrm{a}}$ & 1.0 \\
\hline Fibre $(\mathrm{g})$ & $21^{\mathrm{a}}$ & 1 & $22^{a}$ & 1 & $20^{\mathrm{a}}$ & 1 & $20^{\mathrm{a}}$ & 3 & $20^{a}$ & 2 & $18^{\mathrm{a}}$ & 2 \\
\hline $\mathrm{Ca}(\mathrm{mg})^{\star}$ & $908^{a}$ & 55 & $625^{\mathrm{b}}$ & 36 & $897^{a}$ & 86 & $758^{\mathrm{b}, \mathrm{c}}$ & 47 & $837^{a}$ & 57 & $903^{a, c}$ & 130 \\
\hline $\mathrm{K}(\mathrm{g})$ & $2 \cdot 7^{\mathrm{a}}$ & 0.1 & $2 \cdot 4^{\mathrm{a}}$ & 0.2 & $2 \cdot 5^{\mathrm{a}}$ & 0.2 & $2 \cdot 3^{\mathrm{a}}$ & 0.1 & $2 \cdot 6^{\mathrm{a}}$ & 0.2 & $2 \cdot 5^{\mathrm{a}}$ & 0.3 \\
\hline $\mathrm{Na}(\mathrm{g})$ & $3 \cdot 2^{\mathrm{a}}$ & 0.2 & $2 \cdot 1^{\mathrm{b}}$ & 0.1 & $3 \cdot 0^{\mathrm{a}}$ & 0.2 & $2 \cdot 1^{\mathrm{b}}$ & 0.1 & $3 \cdot 3^{a}$ & 0.2 & $2 \cdot 9^{c}$ & 0.2 \\
\hline $\mathrm{Fe}(\mathrm{mg})^{*}$ & $17^{\mathrm{a}}$ & 1 & $15^{\mathrm{a}}$ & 1 & $16^{a}$ & 2 & $13^{\mathrm{a}}$ & 1 & $14^{\mathrm{a}}$ & 1 & $18^{\mathrm{a}}$ & 4 \\
\hline $\mathrm{Mg}(\mathrm{mg})^{\star}$ & $275^{\mathrm{a}}$ & 13 & $244^{a}$ & 21 & $274^{a}$ & 20 & $230^{a}$ & 15 & $270^{\mathrm{a}}$ & 28 & $252^{\mathrm{a}}$ & 30 \\
\hline $\mathrm{Zn}(\mathrm{mg})$ & $9 \cdot 7^{\mathrm{a}}$ & 0.7 & $7 \cdot 1^{\mathrm{a}}$ & 0.6 & $9 \cdot 5^{\mathrm{a}}$ & 0.8 & $7 \cdot 3^{\mathrm{b}, \mathrm{c}}$ & 0.5 & $9 \cdot 4^{\mathrm{a}}$ & 0.8 & $9 \cdot 3^{a, c}$ & 0.9 \\
\hline Vitamin A (RE) & $1362^{a}$ & 166 & $1398^{\mathrm{a}}$ & 164 & $1132^{a}$ & 197 & $1453^{a}$ & 248 & $1332^{\mathrm{a}}$ & 251 & $1065^{a}$ & 130 \\
\hline Vitamin C (mg) & $127^{\mathrm{a}}$ & 15 & $127^{\mathrm{a}}$ & 12 & $114^{\mathrm{a}}$ & 22 & $130^{\mathrm{a}}$ & 16 & $113^{\mathrm{a}}$ & 18 & $120^{\mathrm{a}}$ & 30 \\
\hline Vitamin D $(\mu \mathrm{g})$ & $3.72^{\mathrm{a}}$ & 0.42 & $2 \cdot 30^{\mathrm{b}}$ & 0.37 & $4 \cdot 00^{\mathrm{a}}$ & 0.67 & $2 \cdot 80^{b, c}$ & 0.45 & $4 \cdot 20^{\mathrm{a}}$ & 0.80 & $4 \cdot 52^{\mathrm{a}, \mathrm{c}}$ & 1.05 \\
\hline Vitamin $\mathrm{E}(\mathrm{mg})$ & $8 \cdot 3^{\mathrm{a}}$ & 1.1 & $5 \cdot 9^{\mathrm{a}}$ & 0.7 & $6 \cdot 2^{a}$ & 0.7 & $6 \cdot 0^{\mathrm{a}}$ & 0.6 & $7 \cdot 5^{\mathrm{a}}$ & 0.9 & $5 \cdot 8^{a}$ & 0.8 \\
\hline Vitamin $\mathrm{K}(\mu \mathrm{g})$ & $78^{\mathrm{a}}$ & 16 & $94^{\mathrm{a}}$ & 19 & $47^{a}$ & 11 & $61^{\mathrm{a}}$ & 17 & $63^{\mathrm{a}}$ & 23 & $91^{\mathrm{a}}$ & 18 \\
\hline Thiamin (mg) & $1 \cdot 7^{\mathrm{a}}$ & 0.1 & $1 \cdot 3^{b}$ & 0.1 & $1.3^{\mathrm{b}}$ & 0.1 & $1 \cdot 1^{\mathrm{b}}$ & 0.1 & $1 \cdot 4^{\mathrm{a}, \mathrm{b}}$ & 0.1 & $2 \cdot 2^{\mathrm{b}}$ & 0.5 \\
\hline Riboflavin $(\mathrm{mg})^{*}$ & $1 \cdot 8^{\mathrm{a}}$ & 0.1 & $1.4^{\mathrm{b}}$ & 0.1 & $1.8^{\mathrm{a}}$ & 0.1 & $1.6^{\mathrm{b}}$ & 0.2 & $1.7^{\mathrm{a}}$ & 0.1 & $2 \cdot 8^{\mathrm{c}}$ & 0.6 \\
\hline Niacin (mg) & $21^{\mathrm{a}}$ & 1 & $18^{\mathrm{a}, \mathrm{b}}$ & 1 & $21^{a}$ & 1 & $18^{\mathrm{a}}$ & 1 & $22^{\mathrm{a}}$ & 2 & $26^{\mathrm{b}}$ & 3 \\
\hline Folate $(\mu \mathrm{g})$ & $342^{a}$ & 23 & $304^{a}$ & 25 & $267^{a}$ & 28 & $282^{a}$ & 23 & $263^{a}$ & 18 & $263^{a}$ & 32 \\
\hline Vitamin $B_{6}(m g)^{*}$ & $1.6^{\mathrm{a}}$ & 0.1 & $1.5^{\mathrm{a}}$ & 0.1 & $1.6^{\mathrm{a}}$ & 0.1 & $1.4^{\mathrm{a}}$ & 0.1 & $1.8^{\mathrm{a}}$ & 0.2 & $1.9^{\mathrm{a}}$ & 0.2 \\
\hline Vitamin $B_{12}(\mu \mathrm{g})$ & $3 \cdot 7^{\mathrm{a}}$ & 0.4 & $2 \cdot 1^{\mathrm{b}}$ & 0.2 & $4 \cdot 3^{a}$ & $1 \cdot 2$ & $3.0^{\mathrm{a}}$ & 0.3 & $3 \cdot 7^{\mathrm{a}}$ & 0.4 & $3 \cdot 8^{a}$ & 0.4 \\
\hline
\end{tabular}

LP, low protein group; NP, normal protein group; HP, high protein group; PRO, protein; $\mathrm{CHO}$, carbohydrate; RE, retinol equivalents.

a,b,c,d Mean values within a row with unlike superscript letters were significantly different $(P<0.05$; ANOVA followed by Tukey's post hoc test).

*Data were transformed on the natural logarithm scale before statistical analysis. 
Table 3. Maximum strength as measured by a modified 1 repetition maximum (1 RM) at baseline (BL) and week 12 (12 wk)

(Mean values with their standard errors)

\begin{tabular}{|c|c|c|c|c|c|c|c|c|c|c|c|c|}
\hline \multirow[b]{2}{*}{ Machine (pounds) } & \multicolumn{4}{|c|}{ LP } & \multicolumn{4}{|c|}{ NP } & \multicolumn{4}{|c|}{$\mathrm{HP}$} \\
\hline & $\mathrm{BL}$ & SEM & $12 \mathrm{wk}$ & SEM & $\mathrm{BL}$ & SEM & $12 \mathrm{wk}$ & SEM & $\mathrm{BL}$ & SEM & 12 wk & SEM \\
\hline Chest press & $99^{a}$ & 4 & $128^{b}$ & 8 & $95^{a}$ & 6 & $130^{b}$ & 5 & $83^{a}$ & 6 & $116^{\mathrm{b}}$ & 7 \\
\hline Leg pulldown & $81^{a}$ & 3 & $113^{b}$ & 4 & $88^{a}$ & 5 & $114^{\mathrm{b}}$ & 3 & $78^{a}$ & 4 & $106^{b}$ & 5 \\
\hline Leg press & $280^{a}$ & 15 & $351^{\mathrm{b}}$ & 18 & $277^{a}$ & 19 & $346^{\mathrm{b}}$ & 13 & $275^{a}$ & 24 & $339^{\mathrm{b}}$ & 33 \\
\hline Seated row & $68^{a}$ & 2 & $95^{b}$ & 4 & $69^{a}$ & 4 & $102^{b}$ & 5 & $66^{a}$ & 5 & $92^{\mathrm{b}}$ & 5 \\
\hline Leg extension & $86^{a}$ & 5 & $108^{b}$ & 10 & $93^{a}$ & 6 & $119^{b}$ & 7 & $84^{a}$ & 7 & $100^{\mathrm{b}}$ & 9 \\
\hline Pectoral fly & $78^{a}$ & 3 & $118^{b}$ & 5 & $76^{a}$ & 7 & $118^{b}$ & 3 & $70^{\mathrm{a}}$ & 6 & $109^{b}$ & 8 \\
\hline Adductor & $160^{a}$ & 5 & $219^{b}$ & 10 & $149^{a}$ & 10 & $216^{\mathrm{b}}$ & 11 & $144^{a}$ & 11 & $199^{\mathrm{b}}$ & 16 \\
\hline Bicep curl & $44^{a}$ & 2 & $66^{b}$ & 3 & $45^{\mathrm{a}}$ & 3 & $66^{\mathrm{b}}$ & 3 & $41^{\mathrm{a}}$ & 3 & $66^{b}$ & 4 \\
\hline Tricep extension & $30^{a}$ & 3 & $72^{b}$ & 7 & $34^{a}$ & 4 & $69^{b}$ & 4 & $27^{a}$ & 3 & $73^{b}$ & 7 \\
\hline Leg curl & $57^{\mathrm{a}}$ & 4 & $82^{b}$ & 5 & $61^{\mathrm{a}}$ & 4 & $79^{b}$ & 3 & $61^{a}$ & 6 & $78^{b}$ & 6 \\
\hline Lateral raise & $59^{a}$ & 3 & $87^{b}$ & 4 & $61^{a}$ & 4 & $86^{b}$ & 3 & $61^{a}$ & 5 & $81^{b}$ & 5 \\
\hline Hip extension & $105^{a}$ & 7 & $150^{b}$ & 9 & $112^{\mathrm{a}}$ & 10 & $144^{\mathrm{b}}$ & 10 & $95^{a}$ & 10 & $127^{\mathrm{b}}$ & 12 \\
\hline Shoulder press & $26^{a}$ & 2 & $49^{b}$ & 4 & $29^{a}$ & 4 & $48^{\mathrm{b}}$ & 2 & $20^{\mathrm{a}}$ & 3 & $44^{b}$ & 4 \\
\hline Total muscle strength* & $1178^{a}$ & 42 & $1623^{b}$ & 73 & $1194^{a}$ & 57 & $1646^{\mathrm{b}}$ & 49 & $1067^{a}$ & 79 & $1514^{b}$ & 93 \\
\hline
\end{tabular}

a,b Mean values within a row with unlike superscript letters were significantly different $(P<0.05$; ANOVA followed by Tukey's post hoc test).

* Total muscle strength indicates the sum of the maximal weight lifted (calculated 1 RM) for all thirteen resistance machines.

12 weeks of training (Table 3) with no effect of diet. Starting stepping stages (Table 4) were not significantly different over the 12 weeks or between the diet groups. Also, subjects in all diet groups increased $(P<0.05)$ the final stepping stage reached at week 12 when compared with baseline, but there were no diet differences. Consequently, subjects completed significantly $(P<0.05)$ more stepping stages at week 12 than at baseline. Oxygen costs significantly increased $(P<0.05)$ in all diet groups over the 12 weeks; again, there were no diet differences. Although the aerobic fitness scores increased $(P<0.05)$ for all diets by week 12 , suggesting improvements in cardiovascular fitness, the overall fitness of the subjects remained in the higher risk zone in terms of the health benefit zone (Table 4).

\section{Blood parameters}

Although fasting plasma glucose declined by $0 \cdot 04,0 \cdot 18$ and $0.05 \mathrm{mmol} / \mathrm{l}$ in the LP, NP and HP groups, respectively, no significant time or diet effects were observed over the 12-week intervention (Table 5). Plasma glucose was $>6.1 \mathrm{mmol} / \mathrm{l}$ in seven (13\%) subjects at baseline compared with three (5\%) by week 12 . Fasting serum insulin levels decreased $(P<0.05)$ in the three diet groups by 43, 66 and $71 \mathrm{pmol} / 1$ in the LP,
NP and HP groups, respectively, but there were no significant diet effects (Table 5). The insulin:glucose ratio decreased $(P<0 \cdot 001)$ over the 12 -week period as did the homeostatic model assessment score estimate of insulin sensitivity (Table 5); however, there were no differences between the diets.

Although fasting serum total cholesterol declined by 0.38 , 0.26 and $0.11 \mathrm{mmol} / 1$ and LDL-cholesterol declined by 0.40 , $0 \cdot 18$ and $0.12 \mathrm{mmol} / 1$ in the LP, NP and HP groups, respectively, no significant time or diet effects were observed for either lipid measure over the 12-week intervention period (Table 5). Moreover, fasting serum HDL-cholesterol increased $(P<0.05)$ in the three diet groups by $0 \cdot 15,0.15$ and $0.13 \mathrm{mmol} /$ 1 in the LP, NP and HP groups, respectively, with no diet effects. Fasting serum TAG levels decreased $(P<0.05)$ in the three diet groups by $0.28,0.50$ and $0.27 \mathrm{mmol} / 1$ in the LP, $\mathrm{NP}$ and HP groups, respectively. Over the 12-week period, all lipid ratios decreased significantly $(P<0 \cdot 05)$, but no significant diet effects were present.

\section{Urine analyses}

There were no significant time or diet effects with the total urine volume measured from the $24 \mathrm{~h}$ urine collection. After 12 weeks, urinary creatinine levels increased $(P<0.05)$ by

Table 4. Muscular endurance as measured by the modified Canadian aerobic fitness test at baseline (BL) and week 12 (12 wk)

(Mean values with their standard errors)

\begin{tabular}{|c|c|c|c|c|c|c|c|c|c|c|c|c|}
\hline & \multicolumn{4}{|c|}{ LP } & \multicolumn{4}{|c|}{ NP } & \multicolumn{4}{|c|}{$\mathrm{HP}$} \\
\hline & $\mathrm{BL}$ & SEM & 12 wk & SEM & $B L$ & SEM & 12 wk & SEM & $B L$ & SEM & 12 wk & SEM \\
\hline Starting stepping stage & $2 \cdot 2^{\mathrm{a}}$ & 0.2 & $2 \cdot 2^{a}$ & $0 \cdot 2$ & $2 \cdot 2^{\mathrm{a}}$ & 0.2 & $2 \cdot 2^{\mathrm{a}}$ & 0.2 & $2 \cdot 1^{\mathrm{a}}$ & 0.0 & $2 \cdot 3^{a}$ & 0.2 \\
\hline Final stepping stage & $3 \cdot 3^{a}$ & 0.2 & $3 \cdot 8^{b}$ & $0 \cdot 2$ & $3 \cdot 4^{a}$ & 0.2 & $3 \cdot 7^{b}$ & 0.3 & $3 \cdot 1^{a}$ & 0.2 & $3 \cdot 6^{\mathrm{b}}$ & 0.3 \\
\hline Stages completed & $1 \cdot 1^{\mathrm{a}}$ & 0.2 & $1.6^{\mathrm{b}}$ & 0.3 & $1 \cdot 2^{a}$ & 0.0 & $1 \cdot 5^{\mathrm{b}}$ & 0.2 & $0.8^{\mathrm{a}}$ & 0.2 & $1 \cdot 3^{b}$ & 0.3 \\
\hline Oxygen cost (litres/min) & $1 \cdot 3^{a}$ & 0.02 & $1.4^{\mathrm{b}}$ & 0.03 & $1 \cdot 3^{a}$ & 0.03 & $1.4^{\mathrm{b}}$ & 0.04 & $1 \cdot 3^{a}$ & 0.04 & $1 \cdot 4^{\mathrm{b}}$ & 0.04 \\
\hline Aerobic fitness score & $338^{a}$ & 13 & $361^{b}$ & 14 & $343^{a}$ & 14 & $372^{b}$ & 17 & $337^{\mathrm{a}}$ & 15 & $363^{b}$ & 15 \\
\hline Health benefit zone & \multicolumn{2}{|c|}{$\mathrm{NI}$} & \multicolumn{2}{|c|}{$\mathrm{NI}$} & \multicolumn{2}{|c|}{$\mathrm{NI}$} & \multicolumn{2}{|c|}{$\mathrm{NI}$} & \multicolumn{2}{|c|}{$\mathrm{NI}$} & \multicolumn{2}{|c|}{$\mathrm{NI}$} \\
\hline
\end{tabular}

LP, low protein group; NP, normal protein group; HP, high protein group; NI, needs improvement.

a,b Mean values within a row with unlike superscript letters were significantly different $(P<0 \cdot 05$; ANOVA followed by Tukey's post hoc test). 
Table 5. Blood biochemistry at baseline (BL) and after the 12-week (12 wk) intervention

(Mean values with their standard errors)

\begin{tabular}{|c|c|c|c|c|c|c|c|c|c|c|c|c|}
\hline & \multicolumn{4}{|c|}{ LP } & \multicolumn{4}{|c|}{ NP } & \multicolumn{4}{|c|}{ HP } \\
\hline & $\mathrm{BL}$ & SEM & $12 \mathrm{wk}$ & SEM & $\mathrm{BL}$ & SEM & $12 \mathrm{wk}$ & SEM & BL & SEM & $12 \mathrm{wk}$ & SEM \\
\hline Fasting glucose $(\mathrm{mmol} / \mathrm{l})$ & $5 \cdot 30^{\mathrm{a}}$ & 0.11 & $5 \cdot 25^{\mathrm{a}}$ & 0.11 & $5 \cdot 6^{\mathrm{a}}$ & 0.44 & $5 \cdot 11^{\mathrm{a}}$ & 0.11 & $5 \cdot 02^{a}$ & 0.21 & $4 \cdot 96^{\mathrm{a}}$ & 0.12 \\
\hline Fasting insulin (pmol/l) & $114^{a}$ & 12 & $71^{\mathrm{b}}$ & 10 & $121^{a}$ & 13 & $55^{\mathrm{b}}$ & 5 & $119^{\mathrm{a}}$ & 9 & $49^{\mathrm{b}}$ & 8 \\
\hline Insulin:glucose ratio & \multirow{2}{*}{\multicolumn{2}{|c|}{$3 \cdot 16^{\mathrm{a}}$}} & \multirow{2}{*}{\multicolumn{2}{|c|}{$\begin{array}{l}1.92^{\mathrm{b}} \\
2.51^{\mathrm{b}}\end{array}$}} & \multirow{2}{*}{\multicolumn{2}{|c|}{$\begin{array}{l}3.24^{\mathrm{a}} \\
4.54^{\mathrm{a}}\end{array}$}} & \multirow{2}{*}{\multicolumn{2}{|c|}{$\begin{array}{l}1.56^{b} \\
1.87^{b}\end{array}$}} & \multicolumn{2}{|c|}{$3.44^{\mathrm{a}}$} & \multicolumn{2}{|c|}{$1.38^{\mathrm{b}}$} \\
\hline HOMA score* & & & & & & & & & \multicolumn{2}{|c|}{$4.04^{\mathrm{a}}$} & \multicolumn{2}{|c|}{$1.65^{\mathrm{b}}$} \\
\hline $\mathrm{TC}(\mathrm{mmol} / \mathrm{l})$ & $5 \cdot 12^{\mathrm{a}}$ & 0.24 & $4 \cdot 74^{a}$ & 0.15 & $5 \cdot 17^{a}$ & 0.26 & $4 \cdot 91^{\mathrm{a}}$ & 0.31 & $4 \cdot 71^{a}$ & 0.22 & $4 \cdot 61^{a}$ & 0.22 \\
\hline LDL-cholesterol $(\mathrm{mmol} / \mathrm{l})$ & $3 \cdot 26^{a}$ & 0.21 & $2 \cdot 86^{\mathrm{a}}$ & $0 \cdot 14$ & $3 \cdot 31^{a}$ & 0.20 & $3 \cdot 13^{\mathrm{a}}$ & 0.24 & $3.01^{a}$ & 0.18 & $2 \cdot 89^{a}$ & 0.19 \\
\hline HDL-cholesterol (mmol/l/) & $1.02^{\mathrm{a}}$ & 0.08 & $1 \cdot 16^{\mathrm{b}}$ & 0.08 & $0.98^{a}$ & 0.07 & $1 \cdot 14^{\mathrm{b}}$ & 0.07 & $1.03^{\mathrm{a}}$ & 0.05 & $1 \cdot 16^{\mathrm{b}}$ & 0.06 \\
\hline TAG $(\mathrm{mmol} / \mathrm{l})$ & $1.85^{\mathrm{a}}$ & 0.18 & $1.57^{\mathrm{b}}$ & 0.12 & $1.92^{\mathrm{a}}$ & 0.22 & $1.41^{\mathrm{b}}$ & 0.16 & $1.50^{\mathrm{a}}$ & 0.19 & $1.23^{\mathrm{b}}$ & 0.11 \\
\hline TC:HDL ratio & $5 \cdot 59^{a}$ & 0.47 & $4 \cdot 33^{b}$ & 0.23 & $5 \cdot 72^{\mathrm{a}}$ & 0.56 & $4.53^{\mathrm{b}}$ & 0.44 & $4 \cdot 81^{a}$ & 0.34 & $4 \cdot 12^{b}$ & 0.24 \\
\hline LDL:HDL ratio & $3.59^{a}$ & 0.36 & $2 \cdot 66^{\mathrm{b}}$ & 0.19 & $3.67^{a}$ & 0.38 & $2.92^{\mathrm{b}}$ & 0.34 & $3 \cdot 10^{\mathrm{a}}$ & 0.27 & $2 \cdot 61^{\mathrm{b}}$ & 0.21 \\
\hline TAG:HDL ratio & $2 \cdot 17^{\mathrm{a}}$ & 0.30 & $1.48^{\mathrm{b}}$ & 0.14 & $2 \cdot 28^{a}$ & 0.42 & $1.35^{\mathrm{b}}$ & 0.23 & $1.57^{\mathrm{a}}$ & 0.23 & $1 \cdot 10^{\mathrm{b}}$ & $0 \cdot 10$ \\
\hline
\end{tabular}

LP, low protein group; NP, normal protein group; HP, high protein group; HOMA, homeostatic model assessment; TC, total cholesterol.

a,b Mean values within a row with unlike superscript letters were significantly different $(P<0.05$; ANOVA followed by Tukey's post hoc test).

* HOMA scores were calculated using the following formula: fasting insulin $(\mu \mathrm{lU} / \mathrm{ml}) \times$ fasting glucose $(\mathrm{mmol} / \mathrm{l}) / 22$.

$0.83,2.27$ and $1.95 \mathrm{mmol} / 1$ in the LP, NP and HP groups, but there were no significant differences between the diets (Table 6). Nitrogen balance was estimated by examining nitrogen dietary intake data and measuring urinary nitrogen excretion. Both time and diet effects were present in the nitrogen intake data as the LP and NP subjects had 4.44 and $2.14 \mathrm{~g}$ decreases $(P<0.05)$, respectively, while the HP subjects had a $2.65 \mathrm{~g}$ increase $(P<0.05)$ in nitrogen intake over the 12 weeks. As a proportion of energy, nitrogen intake did not change in the LP group, increased in the NP group and was nearly double the baseline value in the HP group (Table 6). With respect to nitrogen excretion, habitual levels were lower $(P<0.05)$ in the LP group than in the NP group. After 12 weeks, no significant changes were measured in the LP or NP group and a significant increase $(P<0.05)$ of $2.99 \mathrm{~g}$ was measured in the HP group (Table 6). At baseline, there were no significant differences between the diet groups in terms of nitrogen balance and, overall, subjects in each group were in positive nitrogen balance (Fig. 3). Following the 12week diet and exercise intervention programme, there was an overall time effect $(P<0.05)$ with nitrogen balance and the largest decrease was 4.00 in the LP group, followed by a decrease of 1.74 in the NP group and a slight decline in the HP group of 0.34 (Fig. 3). Overall, both the LP and NP groups were in nitrogen balance and the HP group was in positive nitrogen balance at week 12 .

\section{Discussion}

We hypothesised that the combined effects of a normal protein:carbohydrate ratio with cardiovascular and resistance training would be more beneficial and easier to comply with than either low- or high-protein diets in this target population of women with risk factors for the Met $S^{(7,17)}$. For the most part, this hypothesis was supported. The present study directly evaluated the relationship between protein and carbohydrate by substituting foods in the protein groups (meats, dairy, eggs and nuts) for foods in the higher-carbohydrate group (breads, rice, pasta and cereals), while maintaining total energy and fat levels. Although daily goals were designed to reduce energy intakes by $30 \%$ when compared with habitual intake, subjects reduced their energy intake by $40 \%$ over the 12-week period. All groups reduced their carbohydrate intake, and it has been suggested that greater weight loss that occurs in lower-carbohydrate diets is due to the reduced energy restriction rather than alternative fuel use. Reduced spontaneous energy restriction may occur on low-carbohydrate diets because of their novelty, restriction of accessible

Table 6. Urinary and nitrogen metabolites at baseline (BL) and after 12 weeks (12 wk) of intervention

(Mean values with their standard errors)

\begin{tabular}{|c|c|c|c|c|c|c|c|c|c|c|c|c|}
\hline & \multicolumn{4}{|c|}{ LP } & \multicolumn{4}{|c|}{ NP } & \multicolumn{4}{|c|}{$\mathrm{HP}$} \\
\hline & $\mathrm{BL}$ & SEM & $12 \mathrm{wk}$ & SEM & $\mathrm{BL}$ & SEM & $12 \mathrm{wk}$ & SEM & $\mathrm{BL}$ & SEM & $12 \mathrm{wk}$ & SEM \\
\hline 24-h urine volume (litres) & $1.72^{\mathrm{a}}$ & 0.17 & $1.97^{\mathrm{a}}$ & 0.22 & $2 \cdot 01^{\mathrm{a}}$ & 0.26 & $1.98^{\mathrm{a}}$ & 0.24 & $1 \cdot 77^{\mathrm{a}}$ & 0.15 & $2.03^{\mathrm{a}}$ & 0.24 \\
\hline Creatinine $(\mathrm{mmol} / \mathrm{l})$ & $9.64^{\mathrm{a}}$ & 0.73 & $10 \cdot 47^{\mathrm{b}}$ & 0.73 & $10 \cdot 14^{\mathrm{a}}$ & 1.01 & $12 \cdot 41^{\mathrm{a}}$ & 0.65 & $9 \cdot 53^{\mathrm{a}}$ & 0.64 & $11.48^{\mathrm{b}}$ & 0.75 \\
\hline $\mathrm{N}$ intake $(\mathrm{g})$ & $13 \cdot 31^{\mathrm{a}}$ & 0.61 & $8 \cdot 88^{\mathrm{b}}$ & 0.40 & $14 \cdot 11^{\mathrm{a}}$ & 0.72 & $11.97^{\mathrm{a}}$ & 0.44 & $13.38^{\mathrm{a}}$ & 0.91 & $16 \cdot 03^{\mathrm{d}}$ & 0.81 \\
\hline$N$ excretion $(g)^{\star}$ & $7.92^{\mathrm{a}}$ & 0.61 & $7 \cdot 49^{\mathrm{a}}$ & 0.45 & $10 \cdot 79^{b, c}$ & 0.98 & $10 \cdot 38^{\mathrm{a}, \mathrm{c}}$ & 0.66 & $9 \cdot 18^{\mathrm{a}, \mathrm{c}}$ & 0.50 & $12 \cdot 17^{d}$ & 1.02 \\
\hline $\mathrm{N}$ intake $(\mathrm{mg}) /$ energy intake $(\mathrm{kJ})$ & $1.44^{\mathrm{a}}$ & 0.06 & $1.59^{\mathrm{a}}$ & 0.07 & $1.54^{\mathrm{a}}$ & 0.08 & $2 \cdot 20^{\mathrm{b}}$ & 0.08 & $1.47^{\mathrm{a}}$ & 0.11 & $2 \cdot 94^{\mathrm{c}}$ & 0.15 \\
\hline
\end{tabular}

LP, low protein group; NP, normal protein group; HP, high protein group.

a,b,c,d Mean values within a row with unlike superscript letters were significantly different $(P<0.05$; ANOVA followed by Tukey's post hoc test).

${ }^{*}$ Data were transformed on the natural logarithm scale before statistical analysis. 


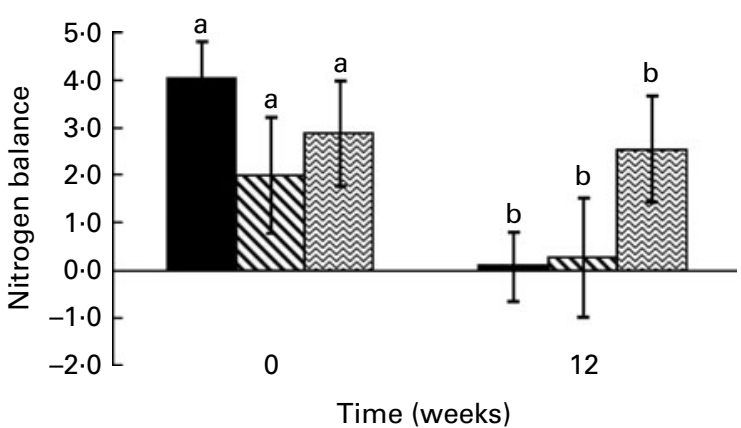

Fig. 3. Nitrogen balances of subjects who completed the 12-week intervention study. Values are means, with standard errors represented by vertical bars. $\mathbf{\square}$, Low protein group; $\mathbf{\Sigma}$ normal protein group; $\approx$, high protein group. Week 0 corresponds to baseline values. Statistical analysis was performed on the change in nitrogen balance from week 0 to 12 after data were transformed on the natural logarithm scale. Mean values within a treatment with unlike letters were significantly different $(P<0.05$; ANOVA followed by Tukey's post hoc test).

foods, reduced appetite due to ketonuria associated with low-carbohydrate diets, or because of enhanced satiety of protein $^{(18,19)}$. The mechanism is unclear, but, gram for gram, protein is more satiating than carbohydrate or fat ${ }^{(20,21)}$. Others ${ }^{(22)}$ have found that higher protein consumption plays a key role in limiting food intake, even in ad libitum recommendations. A recent meta-regression analysis found increased body mass loss with a low-carbohydrate diet (35$41 \%$ ) when energy was controlled for as a covariate ${ }^{(23)}$. There may be a greater demand on protein and amino acids for gluconeogenesis, which is energetically demanding ${ }^{(24)}$

By week 12, the LP, NP and HP groups consumed protein and carbohydrate in the ratios of $1: 3 \cdot 5,1: 2 \cdot 1$ and $1: 1 \cdot 3$. Although the amount of dietary protein in the diet groups was proportionally low, normal and high, all were within the current guidelines for protein of $10-35 \%$ of energy to meet essential nutrient requirements, support metabolic needs and reduce the risk of chronic disease ${ }^{(17,25)}$. All of the diets met the Canadian Dietary Reference Intakes for most nutrients, with the exception that the LP diet provided less $\mathrm{Ca}$, vitamin $\mathrm{D}$ and niacin than the current RDA. Although there were no diet differences in fibre intake, the average intake for each of the groups was below that recommended by Health Canada (at least $25 \mathrm{~g} / \mathrm{d}$ ). Overall, the LP and HP groups had more difficulty complying with their assigned protein:carbohydrate ratios of 1:4 and 1:1 than was experienced by the NP diet group. Despite nutritional counselling and provided recipes, the LP group found it difficult to prepare meals that met the 1:4 ratio that would leave them feeling satisfied. Subjects in this group often complained that they had to eat many 'plain' foods and could not easily combine foods into recipes that they enjoyed. Subjects in the HP group found it challenging to consume such a high quantity of protein, as it produced high satiety before reaching the 1:1 prescription.

Despite differences in the ease with which they could comply with the different diet prescriptions, there were no significant differences between the diets, in the weight loss achieved. Thus, the present trial supports the idea that total energy intake, rather than the macronutrient composition, is the most important determinant of weight loss as reported by several other investigators ${ }^{(26-34)}$. Some weight-loss studies examining macronutrient composition have observed a greater weight loss in their higher-protein groups than their highercarbohydrate counterparts ${ }^{(10,35-38)}$. Reasons for this diet effect have been attributed to higher-protein diets increasing thermogenesis that may subsequently blunt the fall in resting energy expenditure and total energy expenditure, which is often observed during weight loss ${ }^{(37,39,40)}$. Although our HP group lost more weight than the LP group, there was not a clear trend for higher protein:carbohydrate ratios to produce more weight loss or increase the thermic effect of feeding. In fact, the NP group lost more absolute weight than the HP group.

While absolute weight loss may not be affected by macronutrient composition, the distribution of weight loss may be affected. The NP group lost more total fat than the LP group and more body fat as a percentage of body weight than either the LP or HP group. Numerically, the HP group lost more fat than the LP group, though this difference did not reach statistical significance $(P=0 \cdot 07)$. This trend for increased loss of body fat in higher protein:carbohydrate ratio groups has previously been reported ${ }^{(30,38,41)}$, and may be associated with lower fasting insulin concentrations in these groups by the end of the intervention. Although not statistically significant, insulin levels decreased more in our NP and HP groups $v$. the LP group, which may help explain why more body fat was lost in the higher-protein groups. Reduced insulin levels promote the degradation of TAG into NEFA and glycerol. Elevated levels of circulating fatty acids promote their use as a fuel by muscle, which would promote fat loss ${ }^{(42,43)}$. However, lower insulin concentrations do not explain why the NP subjects lost more fat weight than the HP group since insulin values were actually lower in the HP group. Other mechanisms must be at work to explain increased fat loss in the NP group; however, at this time, it is not clear what these might be. In terms of MetS risk reduction, loss of centrally located fat is most important. Waist circumference is a good marker of central adiposity, and all three diets were effective in lowering this measurement. Again, the NP group had larger reductions, suggesting that they would see the largest reduction in the risk for T2D and CVD.

It has been suggested that the loss of lean tissue should not exceed $30 \%$ of total mass lost during weight loss ${ }^{(43)}$. Although the LP group lost significant lean mass, while both the NP and HP groups preserved fat-free mass over the 12-week intervention, all diet groups succeeded in this goal with lean mass losses of $23 \cdot 8,2 \cdot 2$ and $5.5 \%$ in the LP, NP and HP groups, respectively. Exercise, especially resistance training, is known to reduce the loss of lean tissue ${ }^{(44-50)}$, and certainly played a role in preserving fat-free mass in the present study with the incorporated circuit training programme performed by the subjects three times/week.

Furthermore, a significant diet effect was found such that the LP group lost more lean mass than the higher-protein groups, but statistical significance was not quite reached with the HP group $(P=0.059)$. Other clinical trials with similar study designs have found that higher-protein diets may better suppress proteolysis and preserve lean mass in the face of 
energy restriction ${ }^{(28,30,32,37,38)}$. Thus, the higher protein content of the NP and HP diets may be the reason why fat-free mass was better preserved on these plans than the LP diet. Protein intake effects on lean mass are consistent with other studies, in particular the Layman et $a l{ }^{(38)}$ diet and exercise clinical trial whose LP group had a very similar macronutrient composition to the present study (55\% carbohydrate, 15\% protein and $30 \%$ fat). At baseline, subjects in our LP group consumed a mean protein intake of $82 \mathrm{~g} / \mathrm{d}$ or $0.88 \mathrm{~g} / \mathrm{kg}$ per $\mathrm{d}$ compared with a mean protein intake of $55 \mathrm{~g} / \mathrm{d}$ or $0.63 \mathrm{~g} /$ $\mathrm{kg}$ per $\mathrm{d}$ at week 12 , which is below the minimum RDA value of $0.8 \mathrm{~g} / \mathrm{kg}$ per $\mathrm{d}$. Although the LP group was calculated to be in nitrogen balance at the end of the 12-week intervention, this diet group did begin the study with a non-significantly higher nitrogen balance at baseline that decreased more than the NP and HP groups throughout the study. Consequently, decreased protein intake and nitrogen balance may explain, in part, the greater loss of lean mass associated with the LP group. Interestingly, all study subjects were in positive nitrogen balance at baseline, which suggests that they were also in positive energy balance that could well have been contributing to their obesity and related problems. When examining individual data at week 12, some subjects were in negative nitrogen balance, which is an indication that those subjects needed a higher protein intake, as protein is being degraded at a greater rate than it is being synthesised ${ }^{(51)}$. It is important to provide adequate protein to build and maintain muscle, as well as assist with healing and repair ${ }^{(25)}$. Thus, the significant lean mass losses in the LP group suggest that sufficient exogenous protein may not have been provided in this diet prescription.

After completing the 12-week intervention, subjects improved their lipid MetS risk factors for HDL-cholesterol and TAG status. Although the majority of clinical trials that substitute protein for carbohydrate in a low-fat diet have found no changes ${ }^{(35,52,53)}$ or decreases ${ }^{(27,32,41)}$ in HDL-cholesterol for any protein:carbohydrate ratio, we observed increases in all groups in the present study. Our subjects began the study with HDL-cholesterol levels that were very low $(1.01 \mathrm{mmol} / 1 v$. MetS cut-off of $<1.29 \mathrm{mmol} / \mathrm{l})$, thereby leaving much room for improvement. Although the Dattilo \& Kris-Etherton ${ }^{(54)}$ meta-analysis found decreases of $0.007 \mathrm{~mm}$ HDL-cholesterol for every kg of weight loss (which translates into a decrease of $0.042-0.063 \mathrm{mmol} / 1$ in the present study), the addition of exercise in this intervention may have counteracted this effect ${ }^{(7,55,56)}$. Enhanced production of HDL-cholesterol's core protein, apoAI, may have led to the observed increases in HDL-cholesterol ${ }^{(57)}$. According to the Veterans Affairs HDL Cholesterol Intervention trial, a $1 \%$ increase in HDL may constitute a $3 \%$ reduction in mortality, myocardial infarction or CVD risk ${ }^{(58)}$. Thus, the $14 \%$ increase observed in the present study could translate into a substantial reduction in health risks that often result from the MetS. Moreover, the increases in HDL-cholesterol may also help explain why reductions in total cholesterol were on the lower end and did not significantly change over the course of the study. Similarly, TAG levels decreased in all three diet groups. The proportion of subjects with elevated TAG $(>1.7 \mathrm{mmol} / \mathrm{l})$ was reduced from $41 \%$ at baseline to $28 \%$ at week 12 . Combined with the improvements in all three lipid ratios (TC:HDL, LDL:HDL and TAG:HDL), this should have resulted in a significant improvement in insulin sensitivity. Improvements in lipids, insulin resistance and the decreases in blood pressure observed should translate into substantial risk reduction for the MetS, T2D and CVD in the present study population.

The definitive analysis of randomised clinical trials is the intention-to-treat analysis, to preserve the validity of comparisons between treatment groups established by randomisation. However, with such high attrition rates as typically observed in weight-loss studies, data from such an analyses are often incomplete and the analysis is subject to selection bias arising from differences between subjects who complete and those who do not complete the study. Thus, a 'completers' analysis was used in the present study. One of the limitations of the present study is that it is difficult to draw definitive conclusions regarding the safety and efficacy of the prescribed interventions in the general population. That being said, one should not assume that subjects who volunteer for clinical trials are representative of the general population since factors relating to their concern for their own health may motivate their participation. Those who completed the present trial were clearly motivated and committed to the lengthy series of exercise and clinical visits, and thus are probably a more homogeneous population than the general population of women with MetS risk factors. Nonetheless, there is no rationale to suggest that the nature of the differences between diets observed herein would not be observed in those who 'quit' the interventions early. Future research should seek to determine the long-term efficacy of such lifestyle prescriptions and the factors that affect compliance and treatment success in at-risk populations.

\section{Acknowledgements}

The authors would like to thank Alison Duncan, Maggie Laidlaw, Mehrnoosh Kashani, Premila Sathasivam, Diana Philbrick and Mark Dekker for their tremendous assistance during this study. We also thank many of the undergraduate project students (Lisa Labreche, Jane Earle, Gillian Connelly, Matt Palmer and Sharon Chandra) who provided technical assistance with data entry and sample collection. We would like to thank Pat Richards and her staff for their support with the exercise portion of the trial, Dr Brian Wilson for providing training for fitness testing, and Michelle Edwards for her considerable statistical support. This research received no specific grant from any funding agency in the public, commercial or not-for-profit sectors. D. D. C. was the lead student researcher on the study and carried out the majority of the measures, herself. She trained all subjects and is a Certified Fitness Trainer. K. A. M. was the principal investigator, designed the study, provided facilities and resources and wrote the manuscript. The authors have no conflicts of interest to declare.

\section{References}

1. Katzmarzyk PT \& Mason C (2006) Prevalence of class I, II and III obesity in Canada. CMAJ 174, 156-157. 
2. Reaven G (2001) Syndrome X. Curr Treat Options Cardiovasc Med 3, 323-332.

3. Magliano DJ, Shaw JE \& Zimmet PZ (2006) How to best define the metabolic syndrome. Ann Med 38, 34-41.

4. Eckel RH, Grundy SM \& Zimmet PZ (2005) The metabolic syndrome. Lancet 365, 1415-1428.

5. Sorrentino MJ (2000) Cholesterol reduction to prevent CAD. What do the data show? Postgrad Med 108, 40-49.

6. Anonymous (2005) Weight management using lifestyle modification in the prevention and management of type 2 diabetes: rationale and strategies. Clin Diabetes 23, 130-136.

7. Grundy SM, Cleeman JI, Daniels SR, et al. (2006) Diagnosis and management of the metabolic syndrome: an American Heart Association/National Heart, Lung, and Blood Institute scientific statement. Curr Opin Cardiol 21, 1-6.

8. Knowler WC, Barrett-Connor E, Fowler SE, et al. (2002) Reduction in the incidence of type 2 diabetes with lifestyle intervention or metformin. $N$ Engl J Med 346, 393-403.

9. Willett WC (1998) Is dietary fat a major determinant of body fat? Am J Clin Nutr 67, Suppl., 556S-562S.

10. Meckling KA \& Sherfey R (2007) A randomized trial of a hypocaloric high-protein diet, with and without exercise, on weight loss, fitness, and markers of the metabolic syndrome in overweight and obese women. Appl Physiol Nutr Metab 32, 743-752.

11. Meckling KA, Gauthier M, Grubb R, et al. (2002) Effects of a hypocaloric, low-carbohydrate diet on weight loss, blood lipids, blood pressure, glucose tolerance, and body composition in free-living overweight women. Can J Physiol Pharmacol 80, 1095-1105.

12. Poliquin C (1987) Strength Training Theory and Methodology in Level III Theory: National Coaching Certification Program. Ottawa: Coaching Association of Canada.

13. Spreuwenberg LP, Kraemer WJ, Spiering BA, et al. (2006) Influence of exercise order in a resistance-training exercise session. J Strength Cond Res 20, 141-144.

14. Canadian Society of Exercise Physiology (2003) The modified Canadian aerobic fitness test (mCAFT). The Canadian Physical Activity, Fitness and Lifestyle Approach Protocol (CPAFLA). Ottawa: Canadian Society for Exercise Physiology.

15. Karvonen J \& Vuorimaa T (1988) Heart rate and exercise intensity during sports activities. Practical application. Sports Med 5, 303-311.

16. (2001) Executive Summary of The Third Report of The National Cholesterol Education Program (NCEP) Expert Panel on Detection, Evaluation, And Treatment of High Blood Cholesterol In Adults (Adult Treatment Panel III). JAMA 285, 2486-2497.

17. Food and Nutrition Board \& Institute of Medicine (2005) DRI Report: Energy, Carbohydrate, Fiber, Fat, Fatty Acids, Cholesterol, Protein and Amino Acids (Macronutrients). Washington, DC: National Academy Press.

18. Noble CA \& Kushner RF (2006) An update on low-carbohydrate, high-protein diets. Currt Opin Gastroenterol 22, 153-159.

19. Bray GA (2003) Low-carbohydrate diets and realities of weight loss. JAMA 289, 1853-1874.

20. Buchholz AC \& Schoeller DA (2004) Is a calorie a calorie? Clin Nutr 79, 899S-906S.

21. Eisenstein J, Roberts SB, Dallal G, et al. (2002) High-protein weight loss diets: are they safe and do they work? A review of the experimental and epidemiologic data. Nutr Rev $\mathbf{6 0}$, 189-200.

22. Arora SK \& McFarlane SI (2005) The case for low carbohydrate diets in diabetes management. Nutr Metab 2, 16.
23. Krieger JW, Sitren HS, Daniels MJ, et al. (2006) Effects of variation in protein and carbohydrate intake on body mass and composition during energy restriction: a meta-regression. Am J Clin Nutr 83, 260-274.

24. Feinman RD \& Fine EJ (2003) Thermodynamics and metabolic advantage of weight loss diets. Metab Syndr Relat Disord 1, 209-219.

25. Chopra R \& McVay C (2003) Nutritional requirements. Nutrition 19, 187-188.

26. Dumesnil JG, Turgeon J, Tremblay A, et al. (2001) Effect of a low-glycaemic index - low-fat-high protein diet on the atherogenic metabolic risk profile of abdominally obese men. Br J Nutr 86, 557-568.

27. Sargrad KR, Homko C, Mozzoli M, et al. (2005) Effect of high protein vs high carbohydrate intake on insulin sensitivity, body weight, hemoglobin A1c, and blood pressure in patients with type 2 diabetes mellitus. I Am Diet Assoc 105, 573-580.

28. Farnsworth E, Luscombe ND, Noakes M, et al. (2003) Effect of a high-protein, energy-restricted diet on body composition, glycemic control, and lipid concentrations in overweight and obese hyperinsulinemic men and women. Am J Clin Nutr 78, 31-39.

29. Luscombe ND, Clifton PM, Noakes M, et al. (2003) Effect of a high-protein, energy-restricted diet on weight loss and energy expenditure after weight stabilization in hyperinsulinemic subjects. Int J Obes Relat Metab Disord 27, 582-590.

30. Layman DK, Boileau RA, Erickson DJ, et al. (2003) A reduced ratio of dietary carbohydrate to protein improves body composition and blood lipid profiles during weight loss in adult women. J Nutr 133, 411-417.

31. Luscombe ND, Clifton PM \& Noakes M (2002) Effects of energy-restricted diets containing increased protein on weight loss, resting energy expenditure, and the thermic effect of feeding in type 2 diabetes. Diabetes Care $\mathbf{2 5}$, 652-657.

32. Piatti PM, Monti F, Fermo I, et al. (1994) Hypocaloric highprotein diet improves glucose oxidation and spares lean body mass: comparison to hypocaloric high-carbohydrate diet. Metabolism 43, 1481-1487.

33. Due A, Toubro S, Skov AR, et al. (2004) Effect of normal-fat diets, either medium or high in protein, on body weight in overweight subjects: a randomised 1-year trial. Int $J$ Obes Relat Metab Disord 28, 1283-1290.

34. Brinkworth GD, Noakes M, Parker B, et al. (2004) Long-term effects of advice to consume a high-protein, low-fat diet, rather than a conventional weight-loss diet, in obese adults with type 2 diabetes: one-year follow-up of a randomised trial. Diabetologia 47, 1677-1686.

35. Parker B, Noakes M, Luscombe N, et al. (2002) Effect of a high-protein, high-monounsaturated fat weight loss diet on glycemic control and lipid levels in type 2 diabetes. Diabetes Care 25, 425-430.

36. Skov AR, Toubro S, Ronn B, et al. (1999) Randomized trial on protein vs carbohydrate in ad libitum fat reduced diet for the treatment of obesity. Int J Obes Relat Metab Disord 23, 528-536.

37. Baba NH, Sawaya S, Torbay N, et al. (1999) High protein vs high carbohydrate hypoenergetic diet for the treatment of obese hyperinsulinemic subjects. Int J Obes Relat Metab Disord 23, 1202-1206.

38. Layman DK, Evans E, Baum JI, et al. (2005) Dietary protein and exercise have additive effects on body composition during weight loss in adult women. J Nutr 135, 1903-1910. 
39. Leibel RL, Rosenbaum M \& Hirsch J (1995) Changes in energy expenditure resulting from altered body weight. $N$ Engl J Med 332, 621-628.

40. Bessard T, Schutz Y \& Jequier E (1983) Energy expenditure and postprandial thermogenesis in obese women before and after weight loss. Am J Clin Nutr 38, 680-693.

41. Noakes M, Keogh JB, Foster PR, et al. (2005) Effect of an energy-restricted, high-protein, low-fat diet relative to a conventional high-carbohydrate, low-fat diet on weight loss, body composition, nutritional status, and markers of cardiovascular health in obese women. Am J Clin Nutr 81, 1298-1306.

42. Adam-Perrot A, Clifton P \& Brouns F (2006) Low-carbohydrate diets: nutritional and physiological aspects. Obes Rev 7, 49-58.

43. Clasey JL, Bouchard C, Teates CD, et al. (1999) The use of anthropometric and dual-energy X-ray absorptiometry (DXA) measures to estimate total abdominal and abdominal visceral fat in men and women. Obes Res 7, 256-264.

44. National Heart Lung and Blood Institute (2005) Clinical guidelines on the identification, evaluation and treatment of overweight and obesity in adults: the evidence report. Obes Res 6, 51S-209S.

45. Wing RR \& Hill JO (2001) Successful weight loss maintenance. Annu Rev Nutr 21, 323-341.

46. Jakicic JM, Clark K, Coleman E, et al. (2001) American College of Sports Medicine position stand. Appropriate intervention strategies for weight loss and prevention of weight regain for adults. Med Sci Sports Exerc 33, 2145-2156.

47. Jakicic JM (2003) Exercise strategies for the obese patient. Prim Care 30, 393-403.

48. Ballor DL, Katch VL, Becque MD, et al. (1988) Resistance weight training during caloric restriction enhances lean body weight maintenance. Am J Clin Nutr 47, 19-25.

49. Geliebter A, Maher MM, Gerace L, et al. (1997) Effects of strength or aerobic training on body composition, resting metabolic rate, and peak oxygen consumption in obese dieting subjects. Am J Clin Nutr 66, 557-563.

50. Ross R, Pedwell H \& Rissanen J (1995) Response of total and regional lean tissue and skeletal muscle to a program of energy restriction and resistance exercise. Int J Obes Relat Metab Disord 19, 781-787.

51. Lemon PW (1996) Is increased dietary protein necessary or beneficial for individuals with a physically active lifestyle? Nutr Rev 54, S169-S175.

52. Stamets K, Taylor DS, Kunselman A, et al. (2004) A randomized trial of the effects of two types of short-term hypocaloric diets on weight loss in women with polycystic ovary syndrome. Fertil Steril 81, 630-637.

53. Johnston CS, Tjonn SL \& Swan PD (2004) High-protein, lowfat diets are effective for weight loss and favorably alter biomarkers in healthy adults. J Nutr 134, 586-591.

54. Dattilo AM \& Kris-Etherton PM (1992) Effects of weight reduction on blood lipids and lipoproteins: a meta-analysis. Am J Clin Nutr 56, 320-328.

55. Mittendorfer B \& Sidossis LS (2001) Mechanism for the increase in plasma triacylglycerol concentrations after consumption of short-term, high-carbohydrate diets. Am J Clin Nutr 73, 892-899.

56. Robins SJ, Collins D, Wittes JT, et al. (2001) Relation of gemfibrozil treatment and lipid levels with major coronary events: VA-HIT: a randomized controlled trial. JAMA $\mathbf{2 8 5}$, 1585-1591.

57. Brinton EA, Eisenberg S \& Breslow JL (1990) A low-fat diet decreases high density lipoprotein (HDL) cholesterol levels by decreasing HDL apolipoprotein transport rates. J Clin Invest 85, 144-151.

58. Kinosian B, Glick H, Preiss L, et al. (1995) Cholesterol and coronary heart disease: predicting risks in men by changes in levels and ratios. J Investig Med 43, 443-450. 